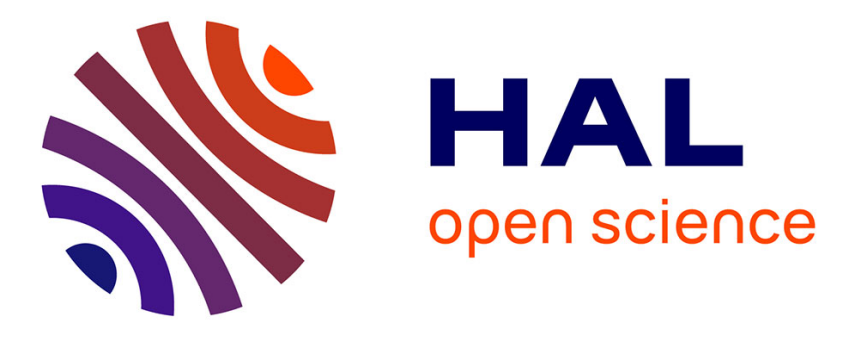

\title{
Modeling Down syndrome in animals from the early stage to the 4.0 models and next
}

Maria del Mar Muñ Iz Moreno, Veronique Brault, Yann Hérault, Maria Del

Mar, Muñiz Moreno, Véronique Brault, Marie-Christine Birling, Guillaume Pavlovic, Yann Herault

\section{To cite this version:}

Maria del Mar Muñ Iz Moreno, Veronique Brault, Yann Hérault, Maria Del Mar, Muñiz Moreno, et al.. Modeling Down syndrome in animals from the early stage to the 4.0 models and next. Progress in brain research, 2019, 10.1016/bs.pbr.2019.08.001 . hal-02378243

\section{HAL Id: hal-02378243 https://hal.science/hal-02378243}

Submitted on 28 Nov 2019

HAL is a multi-disciplinary open access archive for the deposit and dissemination of scientific research documents, whether they are published or not. The documents may come from teaching and research institutions in France or abroad, or from public or private research centers.
L'archive ouverte pluridisciplinaire HAL, est destinée au dépôt et à la diffusion de documents scientifiques de niveau recherche, publiés ou non, émanant des établissements d'enseignement et de recherche français ou étrangers, des laboratoires publics ou privés. 
Running title: DS animal models

Title

Chapter 5. "Modelling Down Syndrome in animals from the early stage to the 4.0 models and next"

\section{Authors}

Maria del Mar Muñiz Moreno ${ }^{1}$, Véronique Brault ${ }^{1}$, Marie-Christine Birling ${ }^{2}$, Guillaume Pavlovic ${ }^{2}$ and Yann Herault ${ }^{1,2}$

\section{Affiliations}

${ }^{1}$ Université de Strasbourg, CNRS, INSERM, Institut de Génétique et de Biologie Moléculaire et Cellulaire, Illkirch, 1 rue Laurent Fries, 67404 Illkirch, France

${ }^{2}$ Université de Strasbourg, CNRS, INSERM, PHENOMIN Institut Clinique de la Souris, Illkirch, 1 rue Laurent Fries, 67404 Illkirch, France

\section{Short Abstract (<200 words)}

The genotype-phenotype relationship and the physiopathology of Down Syndrome (DS) have been explored in the last twenty years with more and more relevant mouse models. From the early age of transgenesis to the new CRISPR/CAS9-derived chromosomal engineering and the transchromosomic technologies, mouse models have been key to identify homologous genes or entire regions homologous to the human chromosome 21 that are necessary or sufficient to induce DS features, to investigate the complexity of the genetic interactions that are involved in DS and to explore therapeutic strategies. In this review we report the new developments made, how genomic data and new genetic tools have deeply changed our way of making models, extended our panel of animal models, and increased our understanding of the neurobiology of the disease. But even if we have made an incredible progress which promises to make DS a curable condition, we are facing new research challenges to nurture our knowledge of DS pathophysiology as a neurodevelopmental disorder with many comorbidities during ageing.

\section{Keyword list}


Genome, animal models, transgenesis, chromosomal engineering, transchromosomic, behaviour and cognition, neurobiology of disease.

\section{Introduction}

The Human chromosome 21 (Hsa21), the smallest autosomic chromosome of the human genome, was mapped and almost fully sequenced 19 years ago (Hattori et al., 2000, Chandler et al., 2007) and was the second chromosome published due to its small size and its major impact when found in 3 copies in Down syndrome (DS) or trisomy 21 . The Hsa21 contains the smallest percentage of all the human genes, a 1.42\% (833 genes on the ENSEMBL assembly GRCh38.v95), and the gene density is around 17.8 genes per Mb, this is quite similar to the overall gene density of 19 genes per Mb. After chromosome 18, chromosome 21 has the highest percentage of long non-coding RNAs (lncRNAs) genes compared to protein coding genes (36.6\% against $27.8 \%$ ) and median percentage of short non-coding elements as miRNAs both in total and per $\mathrm{Mb}$. The sequencing of several widely used lab animal models genomes as Mus musculus (mouse), Rattus norvegicus (rat), Danio rerio (zebrafish), Drosophila melanogaster (fruit fly) and C. elegans (worm), and the great Apes family, the gorilla (Gorilla gorilla), orangutan (Pongo pabelii) and chimpanzee (Pan troglodytes) made possible the use of comparative genomics to identify several genetic alterations and variants associated with specific human diseases. This major progress provided a precise view of the genetic organisation of the Hsa21. The sequence of the mouse genome in 2002 (Waterston et al., 2002) stimulated the development of DS mouse models over the last two decades (Dierssen et al., 2001a, Herault et al., 2017), increasing our understanding of DS conditions and test therapeutic avenues in preclinical models. In the context of DS, the characterisation of the conserved Hsa21 syntenic region in several animal models, such as those on mouse chromosomes 16, 17, 10 and 12 (Toyoda et al., 2002) (this analysis) and on rat chromosomes 20 and 11 (Herault et al., 2017), have served as the basis to develop several models. These carry different partial duplicated regions homologous to Hsa21. These mice are used to map which genes are susceptible to dosage imbalance and contribute to specific observed phenotypes. Thanks to the development of these animal models and their behavioural assessment, we have increased our understanding of DS phenotypes and identified targets for therapeutic interventions.

\section{Animal models for Down syndrome: lesson learnt from the Genomic organisation}

In this first part we will report a state-of-art compilation of all the genomic information available on Hsa21 and the homologues genes found in the most broadly used lab models and other animals where trisomy has occurred spontaneously. Then we will describe in depth all the different genomic elements present on the genome (coding and non-coding elements) in the context of all these species, with a focus on the most commonly used lab animal models of DS. Finally, we will detail the conservation of several highly relevant genes known to be associated with some of the phenotypes observed in people with DS and we will discuss the comorbidities. We will take taking advantage of The International Mouse 
Phenotyping Consortium (IMPC) to get knowledge about the function genes homologous to Hsa21, using their deep-phenotypying in mouse. Although their results is about KO, knowing the function of genes may help to understand their function in DS where they are overexpressed.

We included the following lab animal species and used their genomic sequences: the worm C. elegans (Consortium, 1998); the fruit fly (Adams et al., 2000), rat (Gibbs et al., 2004), and zebrafish (Howe et al., 2013), and some non-human primates (chimpanzee (Consortium, 2005), Orangutan (Locke et al., 2011)). The main reason to include non-human primate is that evolutionary speaking, humans are closer to these species. Moreover, two cases of trisomy were described in chimpanzee (McClure et al., 1969) and both orangutan and gorilla have conserved homologous genes to the Hsa21 in chromosome 22 (Luke et al., 1995), so, there natural trisomies may occur in these species that are analogues to DS, even though none has been described yet.

Based on evolution, the Hsa21 region is more conserved between species that have a more recent common ancestor with Human, such as the Hominidae subclass species. The nuclear chromosome organization is a shared trait between all the Eukaryotic species. However, the rest of the genomic features are specie-specific although up to some degree these features can be conserved i.e. the number of chromosomes, their internal organization or the ratio of the different coding and non-coding elements present on each. To analyse in detail the genome features of these species, we queried the ENSEMBL (www.ensembl.org) database using biomaRt on the 270219 using the genomes assembly's databases version 95 .

\section{I.2 Human chromosome 21 genomic landscape}

\section{I.2.1 Conservation of the Hsa21 genomic landscape}

The apparition of Hsa21 is dated long before the Cercopithecidae divergence ( 55 million years ago). The ancestor of Hsa21 underwent several translocations with other chromosomes in Old World monkeys. Whereas in New World monkeys, it gained a bigger size on the species found (Richard and Dutrillaux, 1998). Thanks to the publication of several ZOO-FISH studies and whole genome sequencing projects, we can more easily and accurately rebuild the evolutionary history and map where the homologous genes of the Hsa21 on different species are located (Figure 1). Although it is important to consider that as the sequenced genomes are not fully completed both the mapping and evolutionary history inferred from these data may continue to develop.

Interestingly, Hsa21 is the autosomal chromosome with the least number and percentage of genes. According to the most recent database, 833 genes are identified in total with 232 protein coding genes, 380 non-coding RNA, 188 pseudogenes and 15 genes to be experimentally confirmed (TEC). Finally, this chromosome holds 8.762 .696 variants described of all kinds.

To address how conserved the orthologs are to the Hsa21 genes on the different species we extracted all the known ortholog genes that diverged by a speciation event, using ENSEMBL biomaRt R package (Brazma et al., 2005), and classified them in three categories:

a) High confidence homologs: genes for whose ENSEMBL has a high confidence in the homology prediction annotation.

b) Remote homologs when the confidence score in the homology was 0 and the sequence similarity was above $15 \%$ of the human gene with the other specie gene.

c) Predicted genes: part from this category are genes with a high percentage of sequence similarity but where the confidence score was unknown. As the members of this category where mostly non-coding genes and predicted genes we decided to label this category as shown. 
Out of the 232 protein coding genes plus 380 non-coding genes found on Hsa21, the number of human genes where we find at least one ortholog in the Hominidae Subclade families of chimpanzee, gorilla and Orangutan are 261, 246 and 232 respectively. Two hundred and thirteen and 208 genes are conserved in rats and mouse genomes respectively. Finally, in zebrafish, fruit fly and worm 154, 98 and 83 homologs were found (Table 1). In all the cases most of the genes found were protein coding genes. Indeed, we are far from having a full description of all the non-coding genome of these species and to know about how evolutionary pressure acts on the non-coding genome. In addition, the overall percentage of non-coding elements is lower in the fruit fly genome compared to the mammal's species (19.62\%). Thus, the number of homologous non-coding genes should be smaller than expected. Furthermore, the zebrafish genome is rich in repetitive sequences and the sequence is far from being resolved; two facts that may be strongly affecting the results about non coding genes.

Approximately 75-million years separate humans and mice or rat in evolutionary time(Waterston et al., 2002). Nevertheless, the chromosomes have rearranged such as the Hsa21 homologous regions have split and the high confidence protein coding homologs genes are found in three orthologous regions on mouse chromosomes. When searching for Hsa21 homologs in the mouse and rat genome we were able to find one previously unknown high confidence mouse homolog located on Mmu12. Interestingly, most non-coding or predicted genes have homologs spread in a bigger number of either mouse or rat chromosomes than the protein coding genes that are highly conserved in chromosome units on mouse Mmu10, 16 and 17 (Mmu for Mus musculus chromosome; Figure 2) and on rats Rno11 and Rno20 (for Rattus Norvegicus chromosome). Additionally, the split Hsa21 regions in the mouse chromosomes are stable as no further inside rearrangements have occurred. Interestingly the non-coding genes inside Hsa21 that are classified as remote orthologs or predicted in mouse and rats, can be found spread in different chromosomes. Furthermore, at the start of Hsa21, on the short arm, between 5.07 and $7.8 \mathrm{Mb}$, there is another syntenic region where we can find a gene inversion in rat, gorilla, chimpanzee and orangutan. Interestingly there is a non-coding enriched region from 7.8 to $14.1 \mathrm{MBs}$ containing one unique high confidence homolog protein coding gene, TPTE, followed by the IGHV1 cluster where all of the genes are found conserved in the animal species spread in several chromosomes and only the IGHV1 cluster is fully maintained as a syntenic block.

Furthermore, there seems to be a high conservation in both the gene identity and the relative synteny of some Hsa21 genes across species. For example, DYRK1A that encodes a dualspecificity tyrosine phosphorylation-regulated kinase has a highly conserved sequence (Figure $3 \mathrm{~A}$ ) in several species and the organisation of its neighbouring genes observed in the Hsa21 is preserved across several mammalian species (Figure 3B). DYRK1A is a highly conserved gene in all the Hominidae subclade and rodent families both in sequence similarity and functional domains conservation. The homology relationship is one to one to one for most of the mammals and has a "one to many" homology relationships with zebrafish as it has two homologous genes called Dyrklaa and Dyrklab. They have an 80.87 and $82.81 \%$ of target sequence similarity and a 78.11 and $78.90 \%$ of query sequence similarity respectively and Dyrk1aa has an assigned Gene Order Conservation score (GOCS) of 50, and a many to many homology relationships with the fruit fly and worm. In the case of fruit fly, the homolog with the higher sequence similarity is $m n b$ with a $41.74 \%$ of target similarity and a $57.27 \%$ of query sequence similarity. The worm has several homologs $m b k-1, Y 111 B 2 A .1, Y 73 B 3 A .16$ and C16A11.10. mbk-1 has the highest homology score with the human DYRK1A, $37.76 \%$ of target sequence homology and $43.64 \%$ of query sequence homology.

\section{I.4 Knowledge on the chromosomal organisation of the Hsa21}


The genome spatial organization inside the nucleus plays an important role in the control of gene expression and in consequence the genome function. Each chromosome can be divided into active and inactive compartments, and these further sub-divided in structural domains called Topologically Associated Domains, or TADs, that are an evolutionary conserved feature of the chromatin organization (Krefting et al., 2018). In the tri-dimensional frame, DNA segments physically interact with some other, more often than with others, these highly interacting sequences are likely to be part of the same TAD.

TADs can be hundreds of kbs long, each isolated from the neighbouring TADs by boundary regions defined by the presence of certain boundaries elements such as CTCF binding sites, DNase I-hypersensitive sites, H3K36 trimethylation, transcription start sites and transcription factors like ZNF274 and SIX5 (Narendra et al., 2016, Hong and Kim, 2017). TADs can be further split in smaller domains referred as sub-TADs, although the definition of these domains and the understanding of their functionality is challenging (Phillips-Cremins et al., 2013). TADs are known to coincide in size with replication timing domains (Wang et al., 2017, Pope et al., 2014), and interestingly TADs are highly statically conserved between cell types and species when looking at the Mb scale (Dixon et al., 2012, Li et al., 2018) although they are certainly dynamic at the kilobase scale and their genomic position can change depending on the cell type or developmental stage (Narendra et al., 2016). Some TADs known to be tissue-specific or development-stage specific.

Spatial chromatin rearrangements disrupting the TADs structure due to genome duplications, deletions or inversions are the known cause of several diseases. For examples, the alteration of EPHA4-PAX3 TAD by disrupting a CTCF- associated boundary generate limb malformations (Lupiáñez et al., 2015); a deletion of 66kb upstream of LMNDB1 promoter deletes a TAD boundary and produces the interaction of three enhancers with the LMNDB1 leading to overexpression of Lamin B1 and causing a rare neurological disorder characterized by a progressive central nervous system demyelination (Giorgio et al., 2015). In cancer TADs seem to be crucial, as 7307 mutations occurring in hESCs CTCF loops anchors were linked to several cancers as identified from the International Cancer Genome Consortium database (Zhang et al., 2011, Ji et al., 2016). Furthermore, some proto-oncogenes are insulated inside subTADs to control their activation (Hnisz et al., 2016). In Down syndrome patients (Zhang et al., 2018) and mouse models (Mowery et al., 2018) derived cell lines, the chromatin structure and accessibility are affected in several ways. I.e. a 22q11 deletion syndrome (22q11DS) DS patient derived lymphoblastoid cell line shows changes in chromatin marks, TADs domains, long-range interactions and gene expression suggesting that large genomic deletions modify nuclear organization and may derive into functional consequences (Zhang et al., 2018). In B-cells derived from Ts65Dn and Dp1Rhr mouse models, the Hsa21 encoded nucleosome binding protein HMGN1 was found critical to produce global chromatin regulatory alterations by increasing $\mathrm{H} 3 \mathrm{~K} 27$ acetylation and was linked to aberrant B-cell phenotypes found in people with DS. Interestingly, some people displayed partial duplications of Hsa21 and some DS models disrupt the TADs structure. Nevertheless, the consequence of these disruption remains unknown and opens an important field of study as the rearrangements in TADs and chromatin structure that may be contribute to the phenotypes. Comparing the diploid Hi-C build neuronal cortex TADs maps showing the human chr21q22 region surrounding DYRK1A and the syntenic region in Mmu16, we can see a high conservation in the TADs structure, boundaries formation and gene content (Figure 4). Thus, it can be certainly useful to characterize the TADs landscape in DS brain cell in animal models to further understand the gene dysregulation and rise of phenotypes in patients carrying specific partial duplications due to the strong conservation of TADs saw in euploids individuals.

\section{Animal models to mimic dosage increase in DS}


Individuals with Down syndrome showed intellectual disabilities and several other abnormal features due to an additional copy of the Hsa21. Animal models already made it possible to get further knowledge on the pathophysiology of the condition. Most of the work have been done on mouse models but other species also contributed to the understanding of DS. Furthermore, rat models have been generated recently using CRISPR/Cas9 genome editing (Birling et al., 2017b) and they will certainly provide new opportunities to address more complex behavior.

\section{II.1 Non-Mammalian in vivo Model Systems II.1.1 Overexpression of genes in the Caenorhabditis elegans (nematode worm)}

C. elegans is a well-established genetic model and shows homology with $13.7 \%$ of the genes from HSA21. To identify poorly characterized HSA21 genes required for nervous system function, Norquist and collaborators (Nordquist et al., 2018) performed a systematic functional characterization of HSA21 orthologs in C. elegans. They did a knockdown screen (RNA interference) and studied behavioural phenotypes caused by loss-of-function mutations in conserved HSA21 orthologs in the nematode. They found 10 HSA21 orthologs that are needed for neuromuscular behaviours: cle-1(COL18A1), cysl-2(CBS), dnsn-1(DONSON), eva-1(EVA1C), mtq-2(N6ATM1), ncam-1(NCAM2), pad-2(POFUT2), pdxk-1(PDXK), rnt1(RUNX1), and unc-26(SYNJ1). Of these ten genes, five are essential for development, based on the lethality phenotype seen in mouse knock-out models. They also found that three of these genes are needed for normal release of the neurotransmitter acetylcholine (the wellknown synaptic geneunc-26 (SYNJ1), as well as uncharacterized genes pdxk-1(PDXK) and mtq-2 (N6ATM1)). As the first systematic functional analysis of HSA21 orthologs, this study may serve as a platform to understand genes that underlie phenotypes associated with DS.

\section{II.1.2 Overexpression of genes in the Danio rerio (Zebrafish)}

Edie and collaborators (Edie et al., 2018) described the use of zebrafish to determine functions of HSA21 genes on early development. They chose cDNAs for 164 HSA21 genes, of which 149 have orthologs in zebrafish. These were transcribed in vitro and injected into 12-cell zebrafish embryos and evaluated up to 5 days post-fertilization in order to perform the genetic dissection of dosage-sensitive gene effects on early development and understand the contribution of individual loci and their combinatorial effects to phenotypes relevant to the etiopathology of DS. Seven cDNAs, including those for superoxide dismutase (SOD1) and 2 novel open reading frames, C21orf84 and C21orf57, resulted in cyclopia and/or U-shaped somites, phenotypes related to decreased sonic-hedgehog (Shh) signalling. The phenotype showed variable penetrance, which was increased with co-injection of 4 cDNAs with C21orf84 (Edie et al., 2018).

Human and zebrafish DYRK1A protein sequence have $75.6 \%$ similarity and same function domains, suggesting an evolutionary conservation. A zebrafish model was used to detect the definite role of excessive expression of DYRK1A in primordial germ cells (PGCs) development during embryogenesis (Liu et al., 2017). DYRK1A mRNA was injected into embryos and the PGCs marker gene vasa and nanos1 were detected. Decreased number and disordered migration of PGCs were shown in zebrafish embryos overexpressing human or zebrafish DYRK1A (Liu et al., 2017). Quantitative proteome analysis showed that embryonic proteins were significantly altered in DYRK1A overexpressed embryos. Thus, overexpression of DYRK1A impairs PGCs development during early embryogenesis by altering key factors in embryos. This work may provide a conceivable mechanism for the gonads and germ cells defects of Down syndrome patients. Nevertheless, it is difficult to compare the level of overexpression achieved by injection of mRNA with the presence of one more copy of $D Y R K 1 A$ in DS. 


\section{II.2 Mammalian in vivo Model Systems II.2.2 The Ts65Dn and the accidental Ts1Cje models: DS mouse models V0}

At the end of the 1990s, two mouse models, Ts65Dn and Ts1Cje, were developed. These have allowed major advances in the understanding of DS. Both models were obtained by extensive screening of a genetic resource (Reeves et al., 1995) or by chance (Sago et al., 1998). These two lines are widely used by the DS community with more than 400 references for Ts65Dn and more than 50 references for Ts1Cje. Those segmental trisomic mouse models, which survive to adulthood and have three copies of multiple genes responsible for the DS phenotype have been used to explore aspects of neurodevelopment and neurodegeneration. These animal models show some but not all the pathological, biochemical, and transcriptional changes observed in DS. They also have the advantage of allowing for the testing of therapeutic agents to restore cognitive function (Herault et al., 2017).

Nevertheless, those models are not perfect. Indeed, the Ts65Dn model has a translocation that results in an extra-small chromosome that holds the Mmu16 region App-Zbtb21 orthologous to Hsa21. These mice are trisomic for about two-thirds of the genes orthologous to Hsa21, but this additional chromosome also carries genes originating from the Mmu17 that are not related to DS disease, including about 46 protein-coding genes, 35 non-protein-coding genes and 35 pseudogenes. Although some Ts65Dn males are fertile (Moore et al., 2010), transmission is typically through the maternal germ line. Mothers are thus trisomic which generally not the case in humans. The Ts1Cje mice do not carry an extra chromosome but is trisomic for the genetic interval Sodl to Mxl orthologous to Hsa21. A translocation between the Mmu16 proximal to Sodl and the very distal region of the Mmu12 occurred, with the Mmu16 breakpoint being between App and Sod1. A partial monosomy of Mmu12 representing about $2 \mathrm{Mb}$ is also present in Ts1Cje mice (Laffaire et al., 2009, Duchon et al., 2011b). This deleted region contains 3 genes that are unrelated to DS but are related to either neuronal proliferation or maturation, embryogenesis or peripheral and central nervous system development.

\section{II.2.1 The early age of transgenic TG, YAC and BAC: DS mouse models V1.0}

The first technological advances in the generation of genetically modified mouse models was developed by Gordon \& Ruddle (1981). They successfully introduced foreign DNA into the pronucleus of one-cell mouse embryo. Initially, mice generated consisted of simple fusion of few kilobases DNA constructs in plasmids, e.g. a specific promoter and a specific cDNA. Early stage of models based on additional transgenesis have been already reviewed (Dierssen et al., 2001b, Dierssen et al., 2009), thus, we concentrated on the insertion of Bacterial Artificial Chromosomes (BACs) or Yeast Artificial Chromosomes (YACs) sequences that can be used to integrate hundreds of kilobases. Unlike plasmid pronuclear injection, large genomic transgenes are more likely to produce copy number dependent transgene expression that is independent of positional effects and better recapitulate endogenous gene expression patterns (Chandler et al., 2007, Giraldo and Montoliu, 2001). YAC models have been developed and analysed to understand the contribution of some DS genes, including DYRK1A, to cognitive function and other features (Guedj et al., 2009, Sebrie et al., 2008, Rachidi et al., 2007, Roubertoux et al., 2006, Branchi et al., 2004, Chabert et al., 2004, Smith and Rubin, 1997, Smith et al., 1997, Smith et al., 1995). The use of BAC transgenesis to model DS is technically complex and time-consuming. More importantly, random integration can result in unexpected phenotypic effects by disruption of an endogenous gene (Smirnov et al., 2018). All these models are valuable tools, but they deserved a very detailed analysis to confirm their integrity. For example, it is important to control that no illegitimate recombination followed by cellular DNA repair activity took place during their random 
insertion into the genome (Yan et al., 2013): the transgene can be inserted at random as a concatemer into the genome. These concatemers are, most frequently, head-to-tail array (Brinster et al., 1981, Bishop and Smith, 1989), with nucleotide deletion or insertion at some ends (Rohan et al., 1990, Merrihew et al., 1996). Integration by concatemers means that the level of overexpression cannot be controlled, it needs to be evaluated in each transgenic line and may not be representative of the increase in expression in people with DS. Several transgenic mice with YAC and BAC containing Hsa21 genes have been developed over the years (Herault et al., 2017, Herault et al., 2012, Dierssen et al., 2009). Most of them concentrate on the Down syndrome critical region (Delabar et al., 1993) and a few on single genes such as the amyloid precursor protein (APP) (Lamb et al., 1993b), regulator of calcineurin 1 (Rcan1) (Xing et al., 2013), Synaptojanin 1 (Synj1) (Voronov et al., 2008) and Dyrk1a (Ahn et al., 2006, Guedj et al., 2012, Nguyen et al., 2018). YAC Transgenic mice containing additional copies of the amyloid precursor protein (APP) gene (Lamb et al., 1993b), have been useful in producing the amyloid beta deposition characteristic of AD and DS, but not the Tau neurofibrillary tangles and cytoskeletal changes that are the hallmarks of these human disorders. Such models are useful in replicating aspects of pathogenesis and allow the testing of therapeutic agents to restore impaired function. For instance, BAC transgenic mice that contain only one copy of the complete human DYRK1A gene showed significant impairment in hippocampal-dependent memory tasks in a Morris water maze. Shifts in both long-term potentiation and long-term depression were observed, which suggest a role for DYRK1A in bidirectional synaptic plasticity. These mice represent a clinically relevant DYRK1A mouse model and provide a valuable tool for the in vivo study of mechanisms that underlie the learning and memory deficit in DS (Ahn et al., 2006).

\section{II.2.3 Chromosome engineering for DS mouse models V2.0}

During the 1990s, the development of chromosome engineering made possible to generate DS monosomic and trisomic lines with precisely selected intervals (Ramirez-Solis et al., 1995, Herault et al., 1998). Chromosome engineering is based on the use if the cre sitespecific recombinase to generate megabase chromosome rearrangements. Basically, the cre enzyme recognize and catalyse site-specific recombination between two lox $P$ attachment sites. When these two loxP sequences are on the same chromosome (i.e. in cis) and in the same orientation, the region between the loxP is deleted. If the loxP are in cis but in opposite direction, the region is inverted. Interestingly, if the loxP are on different chromosome (in trans), translocation events will occur. Duplication and deletion can be obtained in vitro in embryonic stem cells (Ramirez-Solis et al., 1995), or in vivo by targeted meiotic recombination (TAMERE) (Herault et al., 1998). Even if efficient, obtaining DS models though TAMERE can take several years as two mouse models containing loxP are to be generated and then crossed together with a line that expresses cre in male spermatocytes during the zygotene to early pachytene stages (i.e. when chromosome pairing occurs). Despite its complexity, cre/loxP chromosome engineering has resulted in many models of high value for deciphering DS mechanisms (Herault et al., 2012) both in mouse and now in rat (figure 5).

\section{II.2.4 Transchromosomic lines for DS mouse models V3.0}

Transchromosomic (i.e. trans-species aneuploidy) mouse strains are mice that carry an extra chromosome from another species and are thus trisomic only for the genes on this chromosome. Tc1 mouse model (formally called Tc(Hsa21)1TybEmcf) contains an additional Hsa21 (O'Doherty et al., 2005). The Hsa21 was transferred into mouse ES cells using irradiation microcell-mediated chromosome transfer. The Tc1 mouse line was then obtained 
using a classical ES cells injection approach: ES cells were injected into host blastocysts to generate chimeras, the later were then bred to obtained germline transmission.

The Tc1 mice are functionally trisomic for $\sim 120$ protein-coding genes (Ahmed et al., 2013) and most of the human Hsa21 genes are likely expressed at the mRNA, protein and functional levels (Reynolds et al., 2010). Combination of next generation sequencing, comparative genomic hybridization (CGH)-array and Fluorescence in situ Hybridization (FISH) technologies were used to analyse the structure of Tc1 Hsa21 chromosome (Gribble et al., 2013). It revealed multiple structural rearrangements and mutations in genes of interest (such as $A P P)$, likely caused by gamma irradiation during the generation of the model. In addition, Tc1 mice are mosaic for the Hsa21 as this one is lost stochastically. Nevertheless, the Tc1 mouse displays several cognitive, craniofacial and cardiac deficits that are related to DS (O'Doherty et al., 2005, Heise et al., 2015, Watson-Scales et al., 2018, Haas et al., 2013). Altogether the Tc1 model is very informative but we must keep in mind that in this model the human genes should be transcribed and spliced with the mouse machinery and that any interacting proteins coded by the human genes should interact with mouse proteins.

\section{II.2.5 Towards DS mouse models V2.2 with the advanced engineering by CRISPR/Cas9 \& new resources}

In the last few years, CRISPR/Cas9 technological breakthrough and availability of large mutant lines resources are opening brand news possibilities to study DS. CRISPR-mediated rearrangement (CRISMERE) technology promises to replace chromosome engineering and mouse BAC overexpression in DS. The CRISMERE technology is very efficient and fast (Birling et al., 2017b). Two pairs of CRISPR guide RNA (sgRNA) are selected upstream or downstream of the region of interest and are injected with the Cas9 nuclease into one-cell mouse embryos. The Cas 9 protein will generate double strand break at the vicinity of the region of interest and cells reparation mechanisms will result in very frequent structural variation events. The outcomes of the chromosomic recombination are different when Cas9 edits the genome in mitosis phase G1 or G2, with DSBs in cis or in trans (see review (Birling et al., 2017a)). Deletions, inversions and/or duplications can occur in the very same founder and different lines can be obtained from a unique founder. The only limit is the viability of the allele. For instance, a rat line with the deletion of the complete Rno11 region (>24 Mb) was not obtained even if the very same deletion was detected in a founder which had also the duplication. This was not surprising as the monosomy of HSA21 is not viable (and RN011 carries most of the gene located on HSA21). The line with the duplication is viable. High frequency of animals that show deletion, duplication or inversion of the region of interest are indeed observed (Birling et al., 2017a). Because CRISMERE is based on Mammalian cell repair and on the ability to inject CRISPR and Cas9 cocktail in embryos, this technology can likely be used in a large array of species. Rats DS models were already obtained (Birling et al., 2017a) and will help to better understand DS. Indeed, these rat models exhibit more complex and reciprocal social behavior than mouse models as already observed on models for autism spectrum disorders (Hamilton et al., 2014).

\section{Lessons learnt from the mouse models}

\section{III.1 From phenotype to genotype III.1.1 Genotype-phenotype correlation in human}

DS is a complex syndrome with more than 80 possible traits. People with DS are recognizable from their short stature and typical facial features and always have intellectual disability (ID) although with a high range of variability (IQ score from mild ( 50-70) to severe ( 20-35)(Kazemi et al., 2016). In addition to the neurodevelopmental defect leading to ID, 
97.4\% of DS people develop neurodegenerative Alzheimer disease (AD) pathology starting at the age of 40 (Wisniewski et al., 1985, Mann and Esiri, 1989, McCarron et al., 2014, McCarron et al., 2005, Ballard et al., 2016, Head et al., 2015, Wiseman et al., 2015, McCarron et al., 2017). Low muscle tone and delay in the acquisition of both gross and fine motor skills are also present in most of the individual with DS (80\%). However, the other traits are only present in a fraction of the individuals with congenital heart defects (CHD) present in $40-50 \%$ of the cases, acute megakaryoblastic leukemia (AMLK) occurring nearly 500 times more than that of the general population or Hirschprung disease being present in $2.6 \%$ of the infants with DS at a higher frequency than in the euploid population (Lange, 2000, Asim et al., 2015, Friedmacher and Puri, 2013).

Since 1959, more than 60 years ago, we know that DS results from an additional copy of chromosome 21. Nevertheless, the only strong association of Hsa21 specific genes or chromosomal regions to this syndrome are mainly due to studies of partial trisomy. About 95\% of DS cases results from the complete extra copy of Hsa21, whereas rare cases of partial trisomies resulting from robertsonian translocations ( 3\%) have provided invaluable opportunities to study phenotype/genotype correlation and search for the Hsa21 loci responsible for the disease (Aula et al., 1973, Antonarakis, 1998). In 1974, a first review of 14 People with DS with partial trisomies delimited a $17.4 \mathrm{Mb}$ distal 21q22 segment as essential for the development of DS typical features, excluding 65\% of the Hsa21 (Niebuhr, 1974). Development of new cytological techniques such as fluorescent in situ hybridization (FISH) enabled more specific mapping which resulted in the determination of a more specific region of about $0.6 \mathrm{Mb}$ within the 21q22 segment around D21S55 (between the DNA marker D21S17 and the gene ETS2) which was referred as the Down syndrome critical (or candidate) region (DSCR) or Down syndrome minimum chromosomal region (DCR)(Delabar et al., 1993, Rahmani et al., 1989, McCormick et al., 1989). However, this hypothesis of a single DSCR was refuted by Korenberg and collaborators as they reported new cases of people with DS with only Hsa21 proximal duplications (Korenberg et al., 1994, Korenberg et al., 1992, Nelson and Gibbs, 2004). In 2009, two geneticists groups identified genes regions of the Hsa21 associated with specific phenotypes by using high-resolution mapping analyses with Array Comparative Genome Hybridization (CGH), further refuting the idea of a single critical region that would be responsible of all of the DS principal features (Korbel et al., 2009, Lyle et al., 2009). A 2.82 Mb region at 21q22.2-22.3 including the DSCAM gene but excluding the foreseen DSCR genes KCNJ6, RCAN1 and DYRK1A was defined as involved in DS congenital heart disease while a $13 \mathrm{Mb}$ containing also DSCAM was associated with Hirschsprung's disease and another $8.35 \mathrm{Mb}$ region including $R U N X 1$, ERG and ETS was proposed to contribute to both increased risk of transient myeloproliferative disorder (TMD) and acute megakaryoblastic leukemia (AMKL)(Korbel et al., 2009). Finally, they suggested that several regions were involved with ID (Korbel et al., 2009).

\section{III.1.2 Dissecting DS using a compendium of mouse models}

With only a few cases of partial T21 reported in the literature (Roizen and Patterson, 2003, Lyle et al., 2009, Korbel et al., 2009), there has been a need of animal models to further decipher genotype-phenotype relationships. The possibility of making large and specific chromosomal rearrangements using genetic engineering together with close relatedness to human has made of the mouse an invaluable model to study DS. Development of a large panel of targeted segmental trisomy mouse models has played a prominent role in deciphering the genetic complexity of DS. The presence of DS-related phenotypes has supported the validity of those models. 
A major consequence of T21 is an alteration of embryonic development leading to $31-54 \%$ of miscarriage and around 5\% of stillbirth (Morris et al., 1999, Loane et al., 2013, Groen et al., 2017) with the most common congenital anomalies associated being cardiac anomalies (44\%) (Stoll et al., 2015). Fetal and postnatal loss associated to congenital heart defects have also been observed in DS mouse models (Shinohara et al., 2001, O'Doherty et al., 2005, Dunlevy et al., 2010, Li et al., 2007, Raveau et al., 2012, Lana-Elola et al., 2016) Going back to two copies of the 7.7 Mb App-Runx1 region in Ts65Dn mice by crossing it with the Ms5Yah model was able to rescue impaired postnatal viability (Raveau et al., 2012), while the comparison of two trisomic models with CHD, Dp3Tyb (Lana-Elola et al., 2016) and Dp4Yey (Liu et al., 2014), highlighted to a small overlapping region from Mir802 to Kcnj6 to be cricital. Comparing mouse and human data, the $M \times 2-Z b t b 21$ segment present in the Dp3Tyb model was proposed as a critical region as it includes the $1.7 \mathrm{Mb}$ DS CHD critical region (from DSCAM to ZBTB21) proposed by Korbel and collaborators (Korbel et al., 2009). However, no increase in CHD cases compared to wild-type animals could be observed in the Dp6Tyb model bearing a duplication of the lgsf5-Zbtb21 overlapping fragment, suggesting that this region might be necessary but not enough to trigger CHD in mice.

Motor dysfunction and hypotonia are two major concerns in DS. Ts65Dn mice show locomotor deficits and its analysis enabled to partly understand the origin of this phenotype. Impaired coordination observed in those mice could be attributed to cerebellar dysfunction. Moreover, the atrophy of this structure and decreased number of granule cells first reported in the cerebellum of the mice were later reported in people with DS (Baxter et al., 2000, Pinter et al., 2001). Deficit in granular cell proliferation could be attributed to decreased Sonic Hedgehog signaling (Roper et al., 2006) but could not be linked to any specific trisomic gene. The groups of Victor Tybulewicz and Elizabeth Fisher in London used a panel of mouse models with partial trisomies to map the genetic loci responsible for locomotor dysfunction. They excluded homologous regions on Mmu17 and 10 as well as the proximal part of the homologous region on Mmu16 (from Lipi to Mis18a) and pinpointed two small consecutive and non-overlapping regions spanning 3.3 Mb from Mir802 to Zbtb21 whose duplication led to locomotor deficit of the mice in the rotarod test(Watson-Scales et al., 2018). They also found motor neuron degeneration in the $D p(16) 1 Y e y$ model spanning the entire Mmu16 homologous region but could not linked to this phenotype to a specific smaller region, suggesting that this phenotype arise from two or more genes scattered along the Mmu16 region. Nevertheless, this observation in the mouse led to new investigation in people with DS who were found to have the same decrease in motor neurons (Watson-Scales et al., 2018). Further investigations by our laboratory contributed to the analysis of the DS locomotor deficits identifying as new pathological mechanisms and adding to the complexity of the phenotype. Rescue experiment analysis by crossing the Tc1 transchromosomic model with a monosomic model for the Mmu17 Abcg1-U2af1 region partially rescued the locomotor deficit observed in the Tc1 model revealing a role of this region in locomotor function although the trisomic mouse model for this region did not present locomotor deficit(Marechal et al., 2015). We observed a mild locomotor deficit in trisomic mice for the Mmu16 proximal Hspa13-App region that was associated with decreased muscle endurance and oxidative capacity due to decreased mitochondrial content, shedding light on hypotonia and pointing at the Nrip1 gene as candidate for this phenotype (Brault et al., 2015).

Cognitive deficit is by far the most disabling phenotype of DS and is present in all DS people, although with a high variability of severity. People with DS have a specific cognitive profile when compared with other persons with ID syndromes (Siarey et al., 1997, Conners et al., 
2011). They have impaired higher executive functions (Rowe et al., 2006) with difficulties in acquiring new skills(Pennington et al., 2003, Haxby, 1989, Nadel, 2003), verbal short-term memory (M Purser and Jarrold, 2005), visuospatial working (Vicari et al., 2005) and explicit long-term memory while showing relatively preserved emotional processes and implicit learning(Vicari et al., 2000).

Those cognitive phenotypes have been assessed in trisomic mouse models using different tests such as the Y-maze or T-maze for working memory (Hughes, 2004), the long-term novel object recognition (NOR) task for explicit long-term memory (Cohen and Stackman, 2015) or the Morris water maze (MWM) task for spatial learning and memory and memory flexibility (Morris, 1984, D'Hooge and De Deyn, 2001). The Ts65Dn model, trisomic for the Mrp/39Zbtb21 portion of the Mmu16, or the Ts1Cje trisomic for the Scaf4- Zbtb21 region, both containing the DSCR syntenic region were found to have DS-relevant cognitive phenotypes, validating the mouse as a model to study cognitive deficits in DS (Reeves et al., 1995, Escorihuela et al., 1998, Sago et al., 2000, Sago et al., 1998, Fernandez and Garner, 2008, Fernandez and Garner, 2007, Fernandez et al., 2007, Belichenko et al., 2007, Faizi et al., 2011, Rueda et al., 2010, Martinez-Cue et al., 2005, Netzer et al., 2010, Olmos-Serrano et al., 2016b). Moreover, the Tc1 model as well as the full trisomic model containing duplications of the three mouse syntenic regions, or with only trisomic the segment on Mmu16, also recapitulated those phenotypes (Morice et al., 2008, Galante et al., 2009, Yu et al., 2010a, Goodliffe et al., 2016, Olmos-Serrano et al., 2016a). Those models not only reproduced DS cognitive deficits but proved to be invaluable to observe physiological and structural changes in DS. For example, functional explorations of the hippocampus in the Tc1, Dp(16)1Yey and Ts65Dn models all revealed reduced long-term potentiation (LTP) that could explain hippocampal-associated memory deficits observed in the NOR or MWM tests(Morice et al., 2008, Yu et al., 2010c, Kleschevnikov et al., 2004, Siarey et al., 1997) and in people with DS(Pennington et al., 2003). This decreased LTP was further associated to reduced glutamatergic NMDA receptors activation due to an increase in inhibitory gammaaminobutyric (GABA) neurotransmitter (Kleschevnikov et al., 2004, Costa and Grybko, 2005, Kurt et al., 2000).

Further analyses of mouse models carrying a duplication of either the Mmu16, Mmu10 or Mmu17 syntenic region pointed at the importance of the Mmu16 region for most of the DS cognitive deficits (Yu et al., 2010c, Zhang et al., 2014), whereas Dp(17)1Yey and Dp1Yah mice having triplicated regions of the Mmu17 had only some learning impairment (Yu et al., 2010c, Marechal et al., 2019b, Lopes Pereira et al., 2009) and the Dp(10)1Yey showed no learning or memory deficit (Yu et al., 2010c). The Mmu10 syntenic region was further excluded as a DS-ID-relevant region by a subtractive approach crossing the Tc1 model with a mouse model monosomic for the Cstb-Prmt2 region on Mmu10 which showed no rescue of the cognitive deficits observed in the Tc1 model (Duchon et al., 2011a). In order to test the role of the DSCR region as the region necessary for DS cognitive deficits, trisomic (Dp1Rhr, previously named Ts1Rhr) and monosomic (Df1Rhr, previously named Ms1Rhr) mouse models for the Cbr1-Fam3b syntenic region on Mmu16 were generated (Olson et al., 2004). The authors assessed the Dp1Rhr as well as the compound Ts65Dn/Df1Rhr model in the MWM test and found that while the Dp1Rhr model was not by itself sufficient to reproduce the lack of performance of Ts65Dn mice, returning to two copies of the DSCR in the Ts65Dn/Df1Rhr model could rescue spatial memory, suggesting that the DSCR is necessary but not sufficient for this phenotype (Olson et al., 2007). Interestingly in-depth investigations 
in behavior and neurobiology unravelled the impact of the DSCR on neurophysiology and synaptic phenotypes found in DS (Belichenko et al., 2009).

The subtractive strategy was further used to assess the contribution of the single genes Dyrk1a (García-Cerro et al., 2017) or smaller region of the DSCR (Jiang et al., 2015). The complexity of the genetic interaction at work in DS was further demonstrated with the findings of new epistatic interactions when crossing different trisomic models together. Zhang and collaborators found that the increased LTP observed in the hippocampus of $\mathrm{Dp}(17) 1$ Yey mice could be lowered back to normal by mating those mice with $\mathrm{Dp}(10) 1 \mathrm{Yey}$ mice (Zhang et al., 2014), suggesting the genes in each segment have opposing effects on synaptic plasticity. They further showed that, when adding trisomy of the Mmu17 region to the $D p(16) 1 Y e y$ model, the rescue of the deficit observed in the $D p(16) 1$ Yey model by crossing with Ms1Rhr mice was no longer observed, suggesting epistatic interactions between trisomic genes on Mmu17 and trisomic Mmu16 genes (Zhang et al., 2014). Our laboratory went further in deciphering the genes behind such epistatic interaction with $\mathrm{Cbs}$ found on Mmu17 and Dyrk1a on Mmu16 for their impact on DS-related memory deficits (Marechal et al., 2019b).

Although an invariant aspect of DS, craniofacial morphology is the most striking example of the complex genotype-phenotype relationship at play in DS. People with DS typically exhibit overall reduction in skull size with brachcephaly, a round face with close-set eyes, and smaller mandible and maxilla (Guihard-Costa et al., 2006, Farkas et al., 1985). Although different, the murine skull shares the same developmental programs with humans and comparative dysmorphologies have been documented between both the Ts65Dn and Dp(16)1Yey mouse models and the skulls of DS children(Starbuck et al., 2014, Richtsmeier et al., 2002, Richtsmeier et al., 2000, Hill et al., 2007). Both models display overall reduction in size, brachycephaly, reduced mandibular and maxilla size, and reduced interorbital breath (Starbuck et al., 2014, Richtsmeier et al., 2002, Richtsmeier et al., 2000). However, comparing skull morphology of the Ts65Dn model with models encompassing different Ts65Dn sub-regions (Ts1Cje, Scaf4-Mx1; Dp1Rhr, Cbr1-Fam3b; Ts65Dn/Df1Rhr, Mrp/39-Cbr1) showed that Dp1Rhr mice had a very different pattern of dysmorphologies compared to the others, revealing complex interactions (Aldridge et al., 2007, Olson et al., 2004).

\section{III.2 Highlighting the role of candidate genes}

\section{III.2.1 The DSCR genes}

In the search for candidate genes responsible for DS phenotypes, focus has first been made on genes within the DSCR. The most studied gene in this region is the dual-specificity tyrosine (Y)-phosphorylation regulated kinase 1a (DYRK1A). DYRK1A has been found to be implicated in many cellular processes throughout brain development, adult brain function and aging (Tejedor and Hämmerle, 2011, Park and Chung, 2013, Becker et al., 2014, Abbassi et al., 2015, Duchon and Herault, 2016, Arbones et al., 2019). Mouse models, haploinsufficient (Dyrk1a ${ }^{+/-}$mice) (Fotaki et al., 2002, Raveau et al., 2018) or overexpressing Dyrk1a (TgDyrk1a mice) (Altafaj et al., 2001, Ahn et al., 2006, Guedj et al., 2009), have helped to decipher the role of DYRK1A in those different processes. Tg(Dyrk1a) mice recapitulate cognitive phenotypes observed in DS, such as neurodevelopmental delay, locomotor defects, and deficits in visuospatial learning, memory and flexibility (Ahn et al., 2006, Altafaj et al., 2001, Souchet et al., 2014). The change in DYRK1A dosage has shown a huge impact on brain neurogenesis (Guedj et al., 2012). Overexpression of DYRK1A results in 
inhibition of the proliferation and premature differentiation of neuronal cell progenitors (Yabut et al., 2010). DYRK1A impacts cell proliferation via the regulation of some cell cycle proteins like cyclinD1, p21Kip1 and p53 (Park et al., 2010, Najas et al., 2015, Soppa et al., 2014), promoting cell cycle exit (Hämmerle et al., 2011). Dyrk1a ${ }^{+/-}$mice showed that DYRK1A is also implicated in adult neurogenesis by affecting on EGFR-mediated signaling (Ferron et al., 2010). Mouse models have also uncovered the role of DYRK1A in neuritogenesis, synaptogenesis and synaptic activity. Both DYRK1A gain- and loss-of-function models have alterations in dendritic arborization and in density and morphology of dendritic spines (Altafaj et al., 2001, Fotaki et al., 2002, Benavides-Piccione et al., 2005, Lepagnol-Bestel et al., 2009, Martinez de Lagran et al., 2012, Thomazeau et al., 2014, Dang et al., 2018). Defect in axon guidance has been reported linked to the modulatory effect of DYRK1A on FGF signaling via phosphorylation of Sprouty2 (Aranda et al., 2008). Impact of DYRK1A in neuronal activity was visualized by reduced spontaneous neuronal activity, increase in the amplitude of miniature excitatory postsynaptic currents (mEPSCs) in prefrontal cortex pyramidal neurons and by the characterization of modifications in the hippocampal longterm potentiation (LTP) and long-term depression (LTD) in mouse models overexpressing Dyrk1a (Ahn et al., 2006, Martinez de Lagran et al., 2012, Thomazeau et al., 2014, Souchet et al., 2014). Those phenotypes have been linked to impact of DYRK1A on the cytoskeletal machinery via phosphorylation of proteins implicated in actin and microtubules assembly (Colón-Ramos, 2009, Dowjat et al., 2012, Liu et al., 2008, Martinez de Lagran et al., 2012, Park et al., 2012, Aranda et al., 2008, Kaczmarski et al., 2014, Liu et al., 2009, Ori-McKenney et al., 2016, Scales et al., 2009, Ryoo et al., 2008, Woods et al., 2001). Neuronal function was also found to be affected by DYRK1A through impact on expression or translation of key synaptic proteins such as neuroligin1, TrkBT1, Bdnf, AchE-S, and AchE-R (Toiber et al., 2010), on the activity of key transcription factors (NFAT and CREB) or proteins (Gsk3b, Ras, Raf and MEK1) implicated in synaptic plasticity (Arron et al., 2006, Yang et al., 2001, Song et al., 2015, Kelly and Rahmani, 2005), and on its interaction with key proteins involved in either neurotransmitter release or post-synaptic receptor trafficking. DYRK1A overexpression in different mouse models was also found to perturb the excitatory/inhibitory balance toward inhibition and was proposed as a mechanism to explain LTP and memory deficits observed in those models (Ahn et al., 2006, Fernandez et al., 2007, Souchet et al., 2014, Souchet et al., 2015, García-Cerro et al., 2014, Catuara-Solarz et al., 2016). Another DSCR gene, called DSCR1 for DS critical region 1 protein or coding for calcineurin 1 (RCAN1) and an inhibitor of calcineurin-mediated signaling pathways (Fuentes et al., 2000), is also a good candidate for DS neurologic deficits. Both mouse models deficient in or overexpressing RCAN1 show present hippocampal-dependent learning and memory deficits, and impaired LTP and TgRCAN1 presented reduced dendritic spine density on hippocampal pyramidal neurons (Hoeffer et al., 2007, Martin et al., 2012). Change in LTP induction was associated with decreased phosphorylation of the proteins CAMKII and ERK1/2 (Xing et al., 2013). RCAN1 was also reported to impair neurotrophin trafficking leading to aberrant development of the sympathetic nervous system (Patel et al., 2015). Moreover, RCAN1 was implicated in the regulation of mitochondrial function which was also found to be altered in murine DS models (Parra et al., 2018). The DSCR gene KCNJ6 encoding the G protein-coupled inwardly rectifying K+ channel type 2 (GIRK2) has also been studied in the context of DS. GIRK2 plays an important role in cell excitability via control of the membrane resting potential (Lüscher et al., 1997, Luján et al., 2009). Transgenic mice carrying copies of human KCNJ6 were found to have altered cardiac regulation suggesting that this gene contributes to cardiac anomalies 
observed in DS (Lignon et al., 2008). A study with another mouse model trisomic for the mouse Kcnj6 showed that overexpression of this gene induces DS neurological anomalies as trisomic mice had hippocampal-dependent learning and memory deficits associated with hindered depotentiation and accentuated long-term synaptic depression (Cooper et al., 2012). The role of Kcnj6 in DS cognitive deficit was further evidenced by the rescue of the cognitive deficits observed in the Ts65Dn model when crossed with $\mathrm{Kcnj6}^{+/-}$mice (Kleschevnikov et al., 2017). Other candidate genes present within the DSCR are the PCP4 gene coding for the Purkinje cell protein 4, a small calmodulin-binding protein whose overexpression in TgPCP4 mice induces premature neuronal differentiation (Mouton-Liger et al., 2011, Mouton-Liger et al., 2014) while its normalization in the brain of Dp1Rhr trisomic mice rescues the cilia dysfunction observed in this model (Raveau et al., 2017) and DSCAM (Down syndrome cell adhesion molecule), a cell adhesion molecule is responsible for the alteration of actin dynamics in a neuronal cell line of Dp16 mice (Pérez-Núñez et al., 2016). Recently, RNA-Seq and ChIP-Seq analysis of the Dp1Rhr model showed that overexpression of the HMGN1 nucleosome remodeling protein could recapitulate the gene expression modifications observed in this model and this protein was necessary for the B cell acute lymphoblastic leukemia observed in People with DS (Mowery et al., 2018).

\section{III.2.2 More than the DSCR:}

While for some DSCR genes, detailed functional analyses have strongly suggested a contribution of these genes to the DS phenotypes. Studies of mouse models with duplication outside of the DSCR have clearly demonstrated the role of non-DSCR Hsa21 genes. The Col18a1 gene on Mmu10 encoding endostatin, an inhibitor of angiogenesis, was shown in both human and animal models to be at the origin of the resistance against certain solid malignancies observed in DS. RIP140 (Nrip1 in the mouse) upstream of the DSCR and coding for the nuclear receptor-interacting protein 1 was implicated in muscle metabolism and mitochondrial dysfunction observed in DS (Izzo et al., 2014, Brault et al., 2015). Behavioral analysis of mouse models trisomic for the Hsa21 homologous region on Mmu17 clearly indicated the presence in this region of one or more genes implicated in cognitive deficits (Lopes Pereira et al., 2009, Yu et al., 2010b). Further rescue experiment pointed the gene CBS as being responsible for the cognitive phenotype observed in mice trisomic for this region (Marechal et al., 2019a). CBS codes for the Cystathionine-beta-synthase enzyme involved in homocysteine metabolism, with $C B S$ loss-of-function leading to homocystinuria, a metabolic condition linked to intellectual disability (OMIM236200). CBS is also the major enzyme catalyzing the production of $\mathrm{H} 2 \mathrm{~S}$ in the brain, a gasotransmitter implicated in neuronal synaptic plasticity (Hu et al., 2011). CBS was found to genetically interact with $D Y R K 1 A$ although the underlying mechanism of this interaction still is unknown (Marechal et al. 2019). The APP gene present upstream of the DSCR on Mmu16 codes for an integral membrane protein whose proteolysis generates several derivatives as beta-amyloid $(A \beta)$ polypeptide ( $A \beta 40$ and $A \beta 42$ ) and whose amyloid fibrillary form is found in the brain of patients with Alzheimer's disease (AD). Overexpression of this gene is responsible of the neurodegeneration and $A D$ like neuropathological features observed in people with $D S$ (Salehi et al., 2006). App triplication in the mouse Ts65Dn model did not result in A $\beta$ deposit (Lamb et al., 1993a) suggesting that other factors are also required to get the full $A D$ pathology. Still, APP overexpression in transgenic mouse models with the human gene or in the Ts65Dn model causes neuronal degeneration (Ghosal et al., 2009, Simón et al., 2009) which was associated with disruption of nerve growth factor (NGF) transport (Salehi et al., 2006). Triplication of other Hsa21 genes have been subsequently found participating to the 
AD pathology in DS or AD models. Increasing S100B whose gene is present on the Mmu10 syntenic region leads to exacerbated cerebral amyloidosis and reactive gliosis in the Tg2576 APP transgenic mouse model (Mori et al., 2010). DYRK1A and RCAN1 overexpression result in tau hyperphosphorylation, suggesting that these two proteins participate in the formation of the neurofibrillary tangles that are the other hallmark of AD (Ryoo et al., 2008, Wegiel et al., 2011). Moreover, DYRK1A overexpression has been proposed to phosphorylate APP, facilitating APP cleavage by BACE1 and the $\psi$-secretase processing into $A \beta 40$ and $A \beta 42$ (Ryoo et al., 2008, Lee et al., 2003, Vingtdeux et al., 2005, Pathak et al., 2018, García-Cerro et al., 2017). A cooperative interaction has been revealed between DYRK1A and RCAN1 on transcriptional activity via the suppression of the activity of the transcription factor NFAT and resulting in a delay of neuron production during corticogenesis (Kurabayashi and Sanada, 2013). Additionally, Song and collaborators showed that DYRK1A is able to phosphorylate RCAN1, leading to its aggregation (Song et al., 2013). The complexity of the gene interaction at work in DS was further highlighted by the identification of non-Hsa21 isoforms contributing to the phenotypic variation with mutations in the GATA1 transcription factor found on the $X$ chromosome leading to AMLK only in combination with trisomy of the Hsa21 (Crispino, 2005). Recently, some Hsa21 non-coding gene elements have been implicated in DS phenotypes. Five of the 29 miRNAs found of Hsa21 have been associated with DS pathogenesis (Chao et al., 2007, Keck-Wherley et al., 2011, Wang et al., 2013, Brás et al., 2018).

III.2.3 Integration of new knowledge on the function of genes homologous to human chromosome 21 using mouse resource

The "gene dosage effect" hypothesis proposing that DS phenotypes are caused by the cumulative effects of some of the triplicated genes stays the prevailing hypothesis in DS. Hence, knowledge of Hsa21 genes function and expression patterns is an essential step in finding the trisomic genes with potential relevance to the syndrome.

Analysis of gene expression patterns in different tissues and at key stages of organism development enables to detect genes with specific temporal and spatial expression, linking those genes with specific ontogenic processes (Gitton et al., 2002). The mouse remains a resource of choice for gene expression analysis as blocks of orthologous genes expression was shown to be well conserved between mouse and human (Zheng-Bradley et al., 2010). Over the past twenty years, numerous publicly available mouse gene expression databases and digital gene expression atlases such as MAMEP (http://mamep.molgen.mpg.de), EMBRYS (Yokoyama et al., 2009) (http://www.embrys.jp), GenePaint (Carson et al., 2002) (http://www.genepaint.org), EURExpress (Diez-Roux et al., 2011) (http://www.eurexpress.org), EuRe-Gene (Raciti et al., 2008) (http://www.euregene.org/portal), BGEM (Magdaleno et al., 2006, Heintz, 2004) (http://www.gensat.org), the Allen Brain Atlas (Lein et al., 2007) (http://portal.brainmap.org/), EMAGE (http://www.emouseatlas.org/emage) and based on in situ hybridization and high-throughput gene expression data have been developed and offer invaluable tools to visualize gene expression with spatiotemporal resolution. Some of these data are available in some integrated resources such as the Gene Expression Database (GXD, http://www.informatics.jax.org/expression.shtml) and the Gene Expression Omnibus (GEO, https://www.ncbi.nlm.nih.gov/geo/).

With the recent development of single-cell RNA-Sequencing, resolution of gene expression now reaches single cells. This new technique has enabled to dig into cell population diversity and cell type identification revealing rare populations of cells and leading to transcriptome- 
based single cell databases and atlases (DropViz: http://dropviz.org/, (Saunders et al., 2018, Tasic et al., 2016); Single cell expression atlas: https://www.ebi.ac.uk/gxa/sc/home; Adult mouse cortical cell taxonomy: http://casestudies.brain-map.org/celltax, (Tasic et al., 2016)). Using Microwell-Seq, Han and collaborators profiled over fifty mouse organs, tissues and cell lines providing a mouse cell atlas database that will also include proteomic data (such as CyTOF data) and spatial information (such as in situ data) to provide a more complete atlas with multi-omic information (Han et al., 2018). Moreover, new technological advances will allow in the future to obtain multiple omics information as well as serial time point measures from the same cell giving invaluable information to understand how over-expression of given trisomic genes can affect specific cells during specific time points either during development or in the adult (Dey et al., 2015, Macaulay et al., 2015, Harbom et al., 2016) (http://commonfund.nih.gov/singlecell/challenge).

Protein functional analysis has benefit from the development in the 1980s of the Cre/loxP technology in mouse embryonic stem (ES) cells, enabling to produce mutant mice. At the beginning of the 2000s, the International Knockout Mouse consortium (IKMC) federated the Knockout Mouse Project (KOMP) in the US, together with the North American Conditional Mouse Mutagenesis Project (NorCOMM) in Canada and the European Conditional Mouse Mutagenesis Program (EUCOMM) to mutate all the protein-coding genes in the mouse using gene trapping and gene targeting in C57BL/6 mouse ES cells (Collins et al., 2007). Similarly, a collaborative effort was done to provide standardized protocols for the phenotypic characterization of the knockout mice (http://eumorphia.org; http://www.eumodic.org). Since 2012, the International Mouse Phenotyping Consortium (IMPC) has been coordinating all those efforts, generating and phenotyping 20,000 knockout mouse strains. This consortium produces the knock-outs of all the protein coding genes located in syntenic Hsa21 murine regions. All these lines will be available to study systematically, gene per gene to assess the importance of each of them in the DS phenotypes. Today, many knock-out for mouse orthologues to Hsa21 genes are already available and some were already phenotyped through the EMPReSS standard protocol (PMID: 28650483). Systematic knock-out strategies will give new insights about the function of the genes located in Hsa21 and may identify new DS candidate genes. Moreover, the ES clones also allows tissue- or cell-specific conditional gene knockout using spatially and temporally regulated Cre recombinases. Alternatively, the IMPC knock-out lines can also be bred to different trisomic or duplication models to confirm the role of a specific gene in DS phenotype. This approach should also make possible to establish a list of genes as potential targets for treating the disease.

Of the 208 mouse orthologs to Hsa21 genes, only 52 have been selected on a first screen by the IMPC process to produce the complete Knock-out models and do the phenotypical analysis (Table 2). Looking at the different features, 14 classes of phenotypes were observed in embryo or adult state and the main systems altered are behaviour/neurological, mortality (embryo or pre-weaning lethality), homeostasis/metabolism, growth/size/body region. These phenotypes where observed in one or both sexes and in different zygosity states. Fourty-seven genes out of 52 showed more than one phenotype in controlling development, behaviour or metabolism; that are affected in DS. Thus, Hsa21 genes displayed a potential high degree of genetic interaction in diverse biological domains affected in DS, even though knockout phenotypes may not recapitulate the changes associated with DS, as these are linked to increased gene dose.

\section{III.2.4 Finding altered pathways}


As the elevated expression of a Hsa21 gene in DS is a hint of its potential relevance to the pathology, accumulating data on transcriptional and proteomic analyses from human and mouse T21 has been invaluable to find gene dosage sensitive genes that might contribute to DS associated phenotypes. As well as the pathways that could be targeted therapies. Those analyses have revealed a large panel of molecular pathways and cellular processes that are perturbed in DS, however with sometimes contrasting results (Kahlem et al., 2004, Aït Yahya-Graison et al., 2007, Chou et al., 2008, Chrast et al., 2000). Meta-analysis of human and/or murine data revealed perturbation of some pathways involved in many cellular and molecular processes such as cell cycle, cytoskeleton organization, apoptosis, energy metabolism, cellular stress response, immune response, proteasomal activity, transcriptional activity, DNA repair or epigenetic mechanisms (Vilardell et al., 2011, Guedj et al., 2016, Pelleri et al., 2018).

Granular cell precursors in the cerebellum as well as neural crest cells of Ts65Dn mice were found to have reduced response to the mitogenic factor Shh leading to cerebellar hypocellularity, craniofacial dysmorphism and a hypoplastic dorsal mesenchymal protrusion that leads to an atrioventricular septal defect (Baxter et al., 2000, Currier et al., 2012). The mTOR pathway implicated in cell growth and survival was found to be deregulated in the hippocampus of Ts1Cje and Dp(10)1Yey mice, in the brain of Tc1 mice and in the frontal cortex from DS human autopsies (Troca-Marín et al., 2014, Block et al., 2015, Ahmed et al., 2013, Perluigi et al., 2014) and has been associated with the AD pathology (Di Domenico et al., 2018).

Guedj and collaborators (Guedj et al., 2015) found that NFAT signaling was perturbed in the brain of Ts1Cje mice. A mathematical model predicted that increased DSCR1 and DYRK1A trisomic gene dosage could synergistically act to reduce nuclear occupancy of NFAT proteins, leading to misregulation of genes critical to neural, skeletal and immune development (Arron et al., 2006).

Energy metabolism was found to be perturbed in both human DS cell lines and mouse DS models, leading to increased production of reactive oxygen species (ROS) production (Shukkur et al., 2006, Conti et al., 2007, Valenti et al., 2010, Valenti et al., 2011, Brault et al., 2015, Guedj et al., 2016). Ts1Cje mice were shown to have deficit in mitochondrial membrane potential and ATP production (Shukkur et al., 2006), while muscles from Ts3Yah mice were found to have decreased mitochondrial content and a slight increase in mitochondrial membrane permeability (Brault et al., 2015) and Ts65Dn hippocampal neuronal progenitor cells (NPCs) were found to be impaired in mitochondrial ATP synthesis and biogenesis (Valenti et al., 2016, Valenti et al., 2017). Those defects have been linked to alteration of the PGC1 $\alpha /$ Sirt1/AMPK axis (Piccoli et al., 2013, Valenti et al., 2016), of the CAMP/PKA pathway and of proteins involved in mitochondrial fusion (Izzo et al., 2017, Valenti et al., 2017). Hsa21 genes having a role in energy and ROS metabolism are numerous: the MRPL39 and MRPS6 genes coding for mitochondrial ribosomal proteins, ATP5J and ATP5O encoding subunits of the mitochondrial ATP synthase, NDUFV3 encoding a subunit of the NADH-ubiquinone oxidoreductase complex of the respiratory chain or GABPA encoding a subunit of the nuclear respiratory transcription factor involved in activation of cytochrome oxidase expression and nuclear control of mitochondrial function. Moreover, DSCR1 coding for the inhibitor of calcineurin RCAN1 was found to alter mitochondrial fission in transgenic mice overexpressing it (Wong et al., 2015).

\section{Future and perspectives}


The modelling of DS in animals has changed the field of DS research. From the early stages where a few candidate genes were overexpressed using additive transgenesis, to the chromosomal engineering and the transchromosomic strategies, animal models have evolved and boosted research to better understand the pathophysiology of the disease and stimulate therapeutic innovation with many preclinical treatments undergoing pre-clinial/clinical trials for human. As we have shown here, the models have progressed with a better knowledge on genome sequence and organisation in Human and animal models. Both have been key to make new animal models for DS moving from early phase to what now we can call V3.0 models.

DS models, especially in mouse, have been key to achieve progress in the understanding of the DS brain phenotypes. Nevertheless, we have focused on the gene content but have not so far considered higher genomic organisation, like the TADs that are quite well conserved as mentioned above. The development of the genetic toolbox allowing the precise modification of the genome with the additive transgenesis to the up-to-date CRISPR/CAS9 technology to engineer chromosome allows us now to make models in mouse and rat with better efficiency. The use of these techniques may be translated to other species in the future depending on the scientific question asked or the hypothesis to test. Indeed, even if rodents are the most commonly used animal models, we should not forget that anatomical, morphological, and physiological differences will always limit the conclusions obtained from the results obtained in animal species. For example, the complexity of the human brain results from other steps of development with massive expansion of the cortical and cerebellar cortex. Such phenomena's are not present in mouse and rat models but may be mimicked somehow in ferret or in Non-human primate, such as marmoset.

The question now is how can we get better models to go further? Undeniably we should work with the whole set of genes homologous to Hsa21, either bringing together all the trisomies/duplication of regions homologous to $\mathrm{Hsa} 21$ in mouse and rats or use transchromosomic mice. This is supported by recent data showing an epistatic interaction between Dyrk1a and Cbs, located respectively on the Mmu16 and the Mmu17 homologous regions (Marechal et al., 2019b). Thus, it is really a challenge to get together DS models for the 3 chromosomal regions. An alternative is to get new transchromosomic model. Nevertheless, having human genes in a mouse context with human proteins and non-coding elements that are not tailored to work with the mouse components may induce new consequences that are not relevant to DS in people. The rat models may represent an alternative to the mouse with only two main regions to put together (Birling et al., 2017b); although this may be challenging because of elevation in still-birth in this model. Nevertheless, some additional data on their behavior profile are needed before going into this path.

In the current models, the dimension of the genotypic space of DS features is not fully explored. First, we are missing genetic diversity in the mouse models to mimic the variability found in the penetrance and expressivity of features in individuals with DS. Incorporating the genetic diversity represent a major challenge as currently even with up to date initiative such as the Collaborative cross(Iraqi et al., 2012, Churchill et al., 2004), it represents a major challenge to cross all this DS genetic models in various lines. An alternative is to consider studying the phenotype outcomes in an outbred genetic background such as in the rat DS models (Birling et al., 2017b). Then, most of the current studies are done on one model for DS, the Ts65Dn mouse model, that is trisomic for a small subset of genes homologous to Hsa21, leaving aside some key genetic interactions between Hsa21 genes (Marechal et al., 2019b). Finally, more specific to DS, some phenotype will never be recapitulated in the 
mouse brain. For example, the amyloid plaques deposition found in the Alzheimer's disease (AD) brain in people with DS is not present in the brain of DS mouse models. This is due to the change in 3 amino-acid residues found in the sequence of the amyloid beta peptide derived from the mouse gene compared to the human. Thus, new humanized models at least for the App gene should be generated with a humanized App to better mimic the AD in DS.

One way or another, the discovery of target genes from the Hsa21 homologous region will benefit from the direct use of the CRISPR/Cas9 technologies and the quick expansion of gene knock-out resource, done by the IMPC (www.mousephenotype.org). Thus, having access to a complete repertoire of mutants for genes homologous to Hsa21 represents a challenging goal that we should aim to complete linking with the IMPC. Nonetheless what have been achieved so far to mimic DS trisomy is tandem duplication, except for the Ts65Dn mouse model that is carrying a small segregating chromosome with the Mmu16 homologous region together with a small centromeric part of the Mmu17 containing non-homologous Hsa21 genes. Thus, we should either refine the Ts65Dn model by removing the non-homologous region to Hsa21 or generate a new model with a segregating chromosome containing all the main regions homologous to Hsa21. This will also bring together the same context and organization, but the tools needed to achieve this goal are still to be either improved or described.

Overall, the transposition of brain cognitive phenotype between human and animal models is still a challenge. Even though we can assess certain implicit or explicit memory functions in animal models, a standardization of methods may reduce the variability observed between datasets and increase the reproducibility of the results. The rat represents a new opportunity to investigate cognitive deficit in DS and to test preclinical drugs but we may consider other species in the future even more closely related to human.

\section{Acknowledgment}

\section{References}

ABBASSI, R., JOHNS, T. G., KASSIOU, M. \& MUNOZ, L. 2015. DYRK1A in neurodegeneration and cancer: Molecular basis and clinical implications. Pharmacol Ther, 151, 87-98.

ADAMS, M. D., CELNIKER, S. E., HOLT, R. A., EVANS, C. A., GOCAYNE, J. D., AMANATIDES, P. G., SCHERER, S. E., LI, P. W., HOSKINS, R. A., GALLE, R. F., GEORGE, R. A., LEWIS, S. E., RICHARDS, S., ASHBURNER, M., HENDERSON, S. N., SUTTON, G. G., WORTMAN, J. R., YANDELL, M. D., ZHANG, Q., CHEN, L. X., BRANDON, R. C., ROGERS, Y. H., BLAZEJ, R. G., CHAMPE, M., PFEIFFER, B. D., WAN, K. H., DOYLE, C., BAXTER, E. G., HELT, G., NELSON, C. R., GABOR, G. L., ABRIL, J. F., AGBAYANI, A., AN, H. J., ANDREWSPFANNKOCH, C., BALDWIN, D., BALLEW, R. M., BASU, A., BAXENDALE, J., BAYRAKTAROGLU, L., BEASLEY, E. M., BEESON, K. Y., BENOS, P. V., BERMAN, B. P., BHANDARI, D., BOLSHAKOV, S., BORKOVA, D., BOTCHAN, M. R., BOUCK, J., BROKSTEIN, P., BROTTIER, P., BURTIS, K. C., BUSAM, D. A., BUTLER, H., CADIEU, E., CENTER, A., CHANDRA, I., CHERRY, J. M., CAWLEY, S., DAHLKE, C., DAVENPORT, L. B., DAVIES, P., DE PABLOS, B., DELCHER, A., DENG, Z., MAYS, A. D., DEW, I., DIETZ, S. M., DODSON, K., DOUP, L. E., DOWNES, M., DUGAN-ROCHA, S., DUNKOV, B. C., DUNN, P., DURBIN, K. J., EVANGELISTA, C. C., FERRAZ, C., FERRIERA, S., FLEISCHMANN, W., FOSLER, C., GABRIELIAN, A. E., GARG, N. S., GELBART, W. M., GLASSER, K., GLODEK, A., GONG, F., GORRELL, J. H., GU, Z., GUAN, P., HARRIS, M., HARRIS, N. L., HARVEY, D., 
HEIMAN, T. J., HERNANDEZ, J. R., HOUCK, J., HOSTIN, D., HOUSTON, K. A., HOWLAND, T. J., WEI, M. H., IBEGWAM, C., et al. 2000. The genome sequence of Drosophila melanogaster. Science, 287, 2185-95.

AHMED, M. M., DHANASEKARAN, A. R., TONG, S., WISEMAN, F. K., FISHER, E. M., TYBULEWICZ, V. L. \& GARDINER, K. J. 2013. Protein profiles in Tc1 mice implicate novel pathway perturbations in the Down syndrome brain. Hum Mol Genet, 22, 170924.

AHN, K. J., JEONG, H. K., CHOI, H. S., RYOO, S. R., KIM, Y. J., GOO, J. S., CHOI, S. Y., HAN, J. S., HA, I. \& SONG, W. J. 2006. DYRK1A BAC transgenic mice show altered synaptic plasticity with learning and memory defects. Neurobiol Dis, 22, 463-72.

ALDRIDGE, K., REEVES, R. H., OLSON, L. E. \& RICHTSMEIER, J. T. 2007. Differential effects of trisomy on brain shape and volume in related aneuploid mouse models. Am J Med Genet A, 143A, 1060-1070.

ALTAFAJ, X., DIERSSEN, M., BAAMONDE, C., MARTí, E., VISA, J., GUIMERÀ, J., OSET, M., GONZÁLEZ, J. R., FLÓREZ, J., FILLAT, C. \& ESTIVILL, X. 2001. Neurodevelopmental delay, motor abnormalities and cognitive deficits in transgenic mice overexpressing Dyrk1A (minibrain), a murine model of Down's syndrome. Hum Mol Genet, 10, 191523.

ANTONARAKIS, S. E. 1998. 10 years of Genomics, chromosome 21, and Down syndrome. Genomics, 51, 1-16.

ARANDA, S., ALVAREZ, M., TURRÓ, S., LAGUNA, A. \& DE LA LUNA, S. 2008. Sprouty2mediated inhibition of fibroblast growth factor signaling is modulated by the protein kinase DYRK1A. Mol Cell Biol, 28, 5899-911.

ARBONES, M. L., THOMAZEAU, A., NAKANO-KOBAYASHI, A., HAGIWARA, M. \& DELABAR, J. M. 2019. DYRK1A and cognition: A lifelong relationship. Pharmacol Ther, 194, 199221.

ARRON, J. R., WINSLOW, M. M., POLLERI, A., CHANG, C. P., WU, H., GAO, X., NEILSON, J. R., CHEN, L., HEIT, J. J., KIM, S. K., YAMASAKI, N., MIYAKAWA, T., FRANCKE, U., GRAEF, I. A. \& CRABTREE, G. R. 2006. NFAT dysregulation by increased dosage of DSCR1 and DYRK1A on chromosome 21. Nature, 441, 595-600.

ASIM, A., KUMAR, A., MUTHUSWAMY, S., JAIN, S. \& AGARWAL, S. 2015. "Down syndrome: an insight of the disease". J Biomed Sci, 22, 41.

AULA, P., LEISTI, J. \& VON KOSKULL, H. 1973. Partial trisomy 21. Clin Genet, 4, 241-51.

AÏT YAHYA-GRAISON, E., AUBERT, J., DAUPHINOT, L., RIVALS, I., PRIEUR, M., GOLFIER, G., ROSSIER, J., PERSONNAZ, L., CREAU, N., BLÉHAUT, H., ROBIN, S., DELABAR, J. M. \& POTIER, M. C. 2007. Classification of human chromosome 21 gene-expression variations in Down syndrome: impact on disease phenotypes. Am J Hum Genet, 81, 475-91.

BALLARD, C., MOBLEY, W., HARDY, J., WILLIAMS, G. \& CORBETT, A. 2016. Dementia in Down's syndrome. Lancet Neurology, 15, 622-636.

BAXTER, L. L., MORAN, T. H., RICHTSMEIER, J. T., TRONCOSO, J. \& REEVES, R. H. 2000. Discovery and genetic localization of Down syndrome cerebellar phenotypes using the Ts65Dn mouse. Hum Mol Genet, 9, 195-202.

BECKER, W., SOPPA, U. \& TEJEDOR, F. J. 2014. DYRK1A: a potential drug target for multiple Down syndrome neuropathologies. CNS Neurol Disord Drug Targets, 13, 26-33.

BELICHENKO, N. P., BELICHENKO, P. V., KLESCHEVNIKOV, A. M., SALEHI, A., REEVES, R. H. \& MOBLEY, W. C. 2009. The "Down syndrome critical region" is sufficient in the mouse 
model to confer behavioral, neurophysiological, and synaptic phenotypes characteristic of Down syndrome. J Neurosci, 29, 5938-5948.

BELICHENKO, P. V., KLESCHEVNIKOV, A. M., SALEHI, A., EPSTEIN, C. J. \& MOBLEY, W. C. 2007. Synaptic and cognitive abnormalities in mouse models of down syndrome: Exploring genotype-phenotype relationships. Journal of Comparative Neurology, 504, 329-345.

BENAVIDES-PICCIONE, R., DIERSSEN, M., BALLESTEROS-YÁÑEZ, I., MARTÍNEZ DE LAGRÁN, M., ARBONÉS, M. L., FOTAKI, V., DEFELIPE, J. \& ELSTON, G. N. 2005. Alterations in the phenotype of neocortical pyramidal cells in the Dyrk1A+/- mouse. Neurobiol Dis, 20, 115-22.

BIRLING, M. C., HERAULT, Y. \& PAVLOVIC, G. 2017a. Modeling human disease in rodents by CRISPR/Cas9 genome editing. Mamm Genome, 28, 291-301.

BIRLING, M. C., SCHAEFFER, L., ANDRÉ, P., LINDNER, L., MARÉCHAL, D., AYADI, A., SORG, T., PAVLOVIC, G. \& HÉRAULT, Y. 2017b. Efficient and rapid generation of large genomic variants in rats and mice using CRISMERE. Sci Rep, 7, 43331.

BISHOP, J. O. \& SMITH, P. 1989. Mechanism of chromosomal integration of microinjected DNA. Mol Biol Med, 6, 283-98.

BLOCK, A., AHMED, M. M., DHANASEKARAN, A. R., TONG, S. \& GARDINER, K. J. 2015. Sex differences in protein expression in the mouse brain and their perturbations in a model of Down syndrome. Biol Sex Differ, 6, 24.

BONEV, B., MENDELSON COHEN, N., SZABO, Q., FRITSCH, L., PAPADOPOULOS, G. L., LUBLING, Y., XU, X., LV, X., HUGNOT, J. P., TANAY, A. \& CAVALLI, G. 2017. Multiscale 3D Genome Rewiring during Mouse Neural Development. Cell, 171, 557-572.e24.

BRANCHI, I., BICHLER, Z., MINGHETTI, L., DELABAR, J. M., MALCHIODI-ALBEDI, F., GONZALEZ, M. C., CHETTOUH, Z., NICOLINI, A., CHABERT, C., SMITH, D. J., RUBIN, E. M., MIGLIORE-SAMOUR, D. \& ALLEVA, E. 2004. Transgenic mouse in vivo library of human Down syndrome critical region 1: association between DYRK1A overexpression, brain development abnormalities, and cell cycle protein alteration. $J$ Neuropathol Exp Neurol, 63, 429-40.

BRAULT, V., DUCHON, A., ROMESTAING, C., SAHUN, I., POTHION, S., KAROUT, M., BOREL, C., DEMBELE, D., BIZOT, J. C., MESSADDEQ, N., SHARP, A. J., ROUSSEL, D., ANTONARAKIS, S. E., DIERSSEN, M. \& HÉRAULT, Y. 2015. Opposite phenotypes of muscle strength and locomotor function in mouse models of partial trisomy and monosomy 21 for the proximal Hspa13-App region. PLoS Genet, 11, e1005062.

BRAZMA, A., KASPRZYK, A., DE MOOR, B., DAVIS, S., DURINCK, S., HUBER, W. \& MOREAU, Y. 2005. BioMart and Bioconductor: a powerful link between biological databases and microarray data analysis. Bioinformatics, 21, 3439-3440.

BRINSTER, R. L., CHEN, H. Y., TRUMBAUER, M., SENEAR, A. W., WARREN, R. \& PALMITER, R. D. 1981. Somatic expression of herpes thymidine kinase in mice following injection of a fusion gene into eggs. Cell, 27, 223-31.

BRÁS, A., RODRIGUES, A. S., GOMES, B. \& RUEFF, J. 2018. Down syndrome and microRNAs. Biomed Rep, 8, 11-16.

CARSON, J. P., THALLER, C. \& EICHELE, G. 2002. A transcriptome atlas of the mouse brain at cellular resolution. Curr Opin Neurobiol, 12, 562-5.

CATUARA-SOLARZ, S., ESPINOSA-CARRASCO, J., ERB, I., LANGOHR, K., GONZALEZ, J. R., NOTREDAME, C. \& DIERSSEN, M. 2016. Combined Treatment With Environmental Enrichment and (-)-Epigallocatechin-3-Gallate Ameliorates Learning Deficits and Hippocampal Alterations in a Mouse Model of Down Syndrome. eNeuro, 3. 
ChABERT, C., JAMON, M., CHERFOUH, A., DUQUENNE, V., SMITH, D. J., RUBIN, E. \& ROUBERTOUX, P. L. 2004. Functional analysis of genes implicated in Down syndrome: 1. Cognitive abilities in mice transpolygenic for Down Syndrome Chromosomal Region-1 (DCR-1). Behav Genet, 34, 559-69.

CHANDLER, K. J., CHANDLER, R. L., BROECKELMANN, E. M., HOU, Y., SOUTHARD-SMITH, E. M. \& MORTLOCK, D. P. 2007. Relevance of BAC transgene copy number in mice: transgene copy number variation across multiple transgenic lines and correlations with transgene integrity and expression. Mamm Genome, 18, 693-708.

CHAO, H. T., ZOGHBI, H. Y. \& ROSENMUND, C. 2007. MeCP2 controls excitatory synaptic strength by regulating glutamatergic synapse number. Neuron, 56, 58-65.

CHOU, C. Y., LIU, L. Y., CHEN, C. Y., TSAI, C. H., HWA, H. L., CHANG, L. Y., LIN, Y. S. \& HSIEH, F. J. 2008. Gene expression variation increase in trisomy 21 tissues. Mamm Genome, 19, 398-405.

CHRAST, R., SCOTT, H. S., PAPASAVVAS, M. P., ROSSIER, C., ANTONARAKIS, E. S., BARRAS, C., DAVISSON, M. T., SCHMIDT, C., ESTIVILL, X., DIERSSEN, M., PRITCHARD, M. \& ANTONARAKIS, S. E. 2000. The mouse brain transcriptome by SAGE: differences in gene expression between P30 brains of the partial trisomy 16 mouse model of Down syndrome (Ts65Dn) and normals. Genome Res, 10, 2006-21.

CHURCHILL, G., AIREY, D. C., ALLAYEE, H., ANGEL, J. M., ATTIE, A. D., BEATTY, J., BEAVIS, W. D., BELKNAP, J. K., BENNETT, B., BERRETTINI, W., BLEICH, A., BOGUE, M., BROMAN, K. W., BUCK, K. J., BUCKLER, E., BURMEISTER, M., CHESLER, E. J., CHEVERUD, J. M., CLAPCOTE, S., COOK, M. N., COX, R. D., CRABBE, J. C., CRUSIO, W. E., DARVASI, A., DESCHNEPPER, C. F., DOERGE, R. W., FARBER, C. R., FOREJT, J., GAILE, D., GARLOW, S. J., GEIGER, H., GERSHENFELD, H., GORDON, T., GU, J., GU, W. K., DE HAAN, G., HAYES, N. L., HELLER, C., HIMMELBAUER, H., HITZEMANN, R., HUNTER, K., HSU, H. C., IRAQI, F. A., IVANDIC, B., JACOB, H. J., JANSEN, R. C., JJEPSEN, K. J., JOHNSON, D. K., JOHNSON, T. E., KEMPERMANN, G., KENDZIORSKI, C., KOTB, M., KOOY, R. F., LLAMAS, B., LAMMERT, F., LASSALLE, J. M., LOWENSTEIN, P. R., LU, L., LUSISS, A., MANLY, K. F., MARCUCIO, R., MATTHEWS, D., MEDRANO, J. F., MILLER, D. R., MITTLEMAN, G., MOCK, B. A., MOGIL, J. S., MONTAGUTELLI, X., MORAHAN, G., MORRIS, D. G., MOTT, R., NADEAU, J. H., NAGASE, H., NOWAKOWSKI, R. S., O'HARA, B. F., OSADCHUK, A. V., PAGE, G. P., PAIGEN, B., PAIGEN, K., PALMER, A. A., PAN, H. J., PELTONEN-PALOTIE, L., PEIRCE, J., POMP, D., PRAVENEC, M., PROWS, D. R., QI, Z. H., REEVES, R. H., RODER, J., ROSEN, G. D., SCHADT, E. E., SCHALKWYK, L. C., SELTZER, Z., SHIMOMURA, K., SHOU, S. M., SILLANPAA, M. J., SIRACUSA, L. D., SNOECK, H. W., SPEAROW, J. L., SVENSON, K., et al. 2004. The Collaborative Cross, a community resource for the genetic analysis of complex traits. Nature Genetics, 36, 1133-1137.

COHEN, S. J. \& STACKMAN, R. W. 2015. Assessing rodent hippocampal involvement in the novel object recognition task. A review. Behav Brain Res, 285, 105-17.

COLLINS, F. S., FINNELL, R. H., ROSSANT, J. \& WURST, W. 2007. A new partner for the international knockout mouse consortium. Cell, 129, 235.

COLÓN-RAMOS, D. A. 2009. Synapse formation in developing neural circuits. Curr Top Dev Biol, 87, 53-79.

CONNERS, F. A., MOORE, M. S., LOVEALL, S. J. \& MERRILL, E. C. 2011. Memory profiles of Down, Williams, and fragile $X$ syndromes: implications for reading development. J Dev Behav Pediatr, 32, 405-17. 
CONSORTIUM, C. E. S. 1998. Genome sequence of the nematode C. elegans: a platform for investigating biology. Science, 282, 2012-8.

CONSORTIUM, C. S. A. A. 2005. Initial sequence of the chimpanzee genome and comparison with the human genome. Nature, 437, 69-87.

CONTI, A., FABBRINI, F., D'AGOSTINO, P., NEGRI, R., GRECO, D., GENESIO, R., D'ARMIENTO, M., OLLA, C., PALADINI, D., ZANNINI, M. \& NITSCH, L. 2007. Altered expression of mitochondrial and extracellular matrix genes in the heart of human fetuses with chromosome 21 trisomy. BMC Genomics, 8, 268.

COOPER, A., GRIGORYAN, G., GUY-DAVID, L., TSOORY, M. M., CHEN, A. \& REUVENY, E. 2012. Trisomy of the $G$ protein-coupled $K+$ channel gene, Kcnj6, affects reward mechanisms, cognitive functions, and synaptic plasticity in mice. Proc Natl Acad Sci U $S A, 109,2642-7$.

COSTA, A. C. \& GRYBKO, M. J. 2005. Deficits in hippocampal CA1 LTP induced by TBS but not HFS in the Ts65Dn mouse: a model of Down syndrome. Neurosci Lett, 382, 317-22.

CRISPINO, J. D. 2005. GATA1 mutations in Down syndrome: implications for biology and diagnosis of children with transient myeloproliferative disorder and acute megakaryoblastic leukemia. Pediatr Blood Cancer, 44, 40-4.

CURRIER, D. G., POLK, R. C. \& REEVES, R. H. 2012. A Sonic hedgehog (Shh) response deficit in trisomic cells may be a common denominator for multiple features of Down syndrome. Prog Brain Res, 197, 223-36.

D'HOOGE, R. \& DE DEYN, P. P. 2001. Applications of the Morris water maze in the study of learning and memory. Brain Res Brain Res Rev, 36, 60-90.

DANG, T., DUAN, W. Y., YU, B., TONG, D. L., CHENG, C., ZHANG, Y. F., WU, W., YE, K., ZHANG, W. X., WU, M., WU, B. B., AN, Y., QIU, Z. L. \& WU, B. L. 2018. Autism-associated Dyrk1a truncation mutants impair neuronal dendritic and spine growth and interfere with postnatal cortical development. Mol Psychiatry, 23, 747-758.

DELABAR, J. M., THEOPHILE, D., RAHMANI, Z., CHETTOUH, Z., BLOUIN, J. L., PRIEUR, M., NOEL, B. \& SINET, P. M. 1993. Molecular mapping of twenty-four features of Down syndrome on chromosome 21. Eur J Hum Genet, 1, 114-24.

DEY, S. S., KESTER, L., SPANJAARD, B., BIENKO, M. \& VAN OUDENAARDEN, A. 2015. Integrated genome and transcriptome sequencing of the same cell. Nat Biotechnol, 33, 285-289.

DI DOMENICO, F., TRAMUtola, A., FOPPOLI, C., HEAD, E., PERLUIGI, M. \& BUTTERFIELD, D. A. 2018. mTOR in Down syndrome: Role in $A ß$ and tau neuropathology and transition to Alzheimer disease-like dementia. Free Radic Biol Med, 114, 94-101.

DIERSSEN, M., FILLAT, C., CRNIC, L., ARBONES, M., FLOREZ, J. \& ESTIVILL, X. 2001a. Murine models for Down syndrome. Physiol Behav, 73, 859-71.

DIERSSEN, M., FILLAT, C., CRNIC, L., ARBONÉS, M., FLÓREZ, J. \& ESTIVILL, X. 2001b. Murine models for Down syndrome. Physiol Behav, 73, 859-71.

DIERSSEN, M., HERAULT, Y. \& ESTIVILL, X. 2009. Aneuploidy: From a Physiological Mechanism of Variance to Down Syndrome. Physiological Reviews, 89, 887-920.

DIEZ-ROUX, G., BANFI, S., SULTAN, M., GEFFERS, L., ANAND, S., ROZADO, D., MAGEN, A., CANIDIO, E., PAGANI, M., PELUSO, I., LIN-MARQ, N., KOCH, M., BILIO, M., CANTIELLO, I., VERDE, R., DE MASI, C., BIANCHI, S. A., CICCHINI, J., PERROUD, E., MEHMETI, S., DAGAND, E., SCHRINNER, S., NÜRNBERGER, A., SCHMIDT, K., METZ, K., ZWINGMANN, C., BRIESKE, N., SPRINGER, C., HERNANDEZ, A. M., HERZOG, S., GRABBE, F., SIEVERDING, C., FISCHER, B., SCHRADER, K., BROCKMEYER, M., DETTMER, S., HELBIG, 
C., ALUNNI, V., BATTAINI, M. A., MURA, C., HENRICHSEN, C. N., GARCIA-LOPEZ, R., ECHEVARRIA, D., PUELleS, E., GARCIA-CALERO, E., KRUSE, S., UHR, M., KAUCK, C., FENG, G., MILYAEV, N., ONG, C. K., KUMAR, L., LAM, M., SEMPLE, C. A., GYENESEI, A., MUNDLOS, S., RADELOF, U., LEHRACH, H., SARMIENTOS, P., REYMOND, A., DAVIDSON, D. R., DOLLÉ, P., ANTONARAKIS, S. E., YASPO, M. L., MARTINEZ, S., BALDOCK, R. A., EICHELE, G. \& BALLABIO, A. 2011. A high-resolution anatomical atlas of the transcriptome in the mouse embryo. PLoS Biol, 9, e1000582.

DIXON, J. R., SELVARAJ, S., YUE, F., KIM, A., LI, Y., SHEN, Y., HU, M., LIU, J. S. \& REN, B. 2012. Topological domains in mammalian genomes identified by analysis of chromatin interactions. Nature, 485, 376-80.

DOWJAT, K., ADAYEV, T., KACZMARSKI, W., WEGIEL, J. \& HWANG, Y. W. 2012. Gene dosagedependent association of DYRK1A with the cytoskeleton in the brain and lymphocytes of down syndrome patients. J Neuropathol Exp Neurol, 71, 1100-12.

DUCHON, A. \& HERAULT, Y. 2016. DYRK1A, a Dosage-Sensitive Gene Involved in Neurodevelopmental Disorders, Is a Target for Drug Development in Down Syndrome. Front Behav Neurosci, 10, 104.

DUCHON, A., POTHION, S., BRAULT, V., SHARP, A. J., TYBULEWICZ, V. L., FISHER, E. M. \& HERAULT, Y. 2011a. The telomeric part of the human chromosome 21 from Cstb to Prmt2 is not necessary for the locomotor and short-term memory deficits observed in the Tc1 mouse model of Down syndrome. Behav Brain Res, 217, 271-81.

DUCHON, A., RAVEAU, M., CHEVALIER, C., NALESSO, V., SHARP, A. J. \& HERAULT, Y. $2011 b$. Identification of the translocation breakpoints in the Ts65Dn and Ts1Cje mouse lines: relevance for modeling Down syndrome. Mamm Genome, 22, 674-84.

DUNLEVY, L., BENNETT, M., SLENDER, A., LANA-ELOLA, E., TYBULEWICZ, V. L., FISHER, E. M. \& MOHUN, T. 2010. Down's syndrome-like cardiac developmental defects in embryos of the transchromosomic Tc1 mouse. Cardiovasc Res, 88, 287-95.

EDIE, S., ZAGHLOUL, N. A., LEITCH, C. C., KLINEDINST, D. K., LEBRON, J., THOLE, J. F., MCCALLION, A. S., KATSANIS, N. \& REEVES, R. H. 2018. Survey of Human Chromosome 21 Gene Expression Effects on Early Development in. G3 (Bethesda), 8, 2215-2223.

ESCORIHUELA, R. M., VALLINA, I. F., MARTINEZ-CUE, C., BAAMONDE, C., DIERSSEN, M., TOBENA, A., FLOREZ, J. \& FERNANDEZ-TERUEL, A. 1998. Impaired short- and longterm memory in Ts65Dn mice, a model for Down syndrome. Neurosci Lett, 247, 1714.

FAIZI, M., BADER, P. L., TUN, C., ENCARNACION, A., KLESCHEVNIKOV, A., BELICHENKO, P., SAW, N., PRIESTLEY, M., TSIEN, R. W., MOBLEY, W. C. \& SHAMLOO, M. 2011. Comprehensive behavioral phenotyping of Ts65Dn mouse model of Down Syndrome: Activation of pradrenergic receptor by xamoterol as a potential cognitive enhancer. Neurobiology of Disease, 43, 397-413.

FARKAS, L. G., MUNRO, I. R. \& KOLAR, J. C. 1985. Abnormal measurements and disproportions in the face of Down's syndrome patients: preliminary report of an anthropometric study. Plast Reconstr Surg, 75, 159-69.

FERNANDEZ, F. \& GARNER, C. C. 2007. Object recognition memory is conserved in Ts1Cje, a mouse model of Down syndrome. Neurosci Lett, 421, 137-141.

FERNANDEZ, F. \& GARNER, C. C. 2008. Episodic-like memory in Ts65Dn, a mouse model of Down syndrome. Behav Brain Res, 188, 233-7. 
FERNANDEZ, F., MORISHITA, W., ZUNIGA, E., NGUYEN, J., BLANK, M., MALENKA, R. C. \& GARNER, C. C. 2007. Pharmacotherapy for cognitive impairment in a mouse model of Down syndrome. Nat Neurosci, 10, 411-3.

FERRON, S. R., POZO, N., LAGUNA, A., ARANDA, S., PORLAN, E., MORENO, M., FILLAT, C., DE LA LUNA, S., SÁNCHEZ, P., ARBONÉS, M. L. \& FARIÑAS, I. 2010. Regulated segregation of kinase Dyrk1A during asymmetric neural stem cell division is critical for EGFRmediated biased signaling. Cell Stem Cell, 7, 367-79.

FOTAKI, V., DIERSSEN, M., ALCÁNTARA, S., MARTÍNEZ, S., MARTÍ, E., CASAS, C., VISA, J., SORIANO, E., ESTIVILL, X. \& ARBONÉS, M. L. 2002. Dyrk1A haploinsufficiency affects viability and causes developmental delay and abnormal brain morphology in mice. Mol Cell Biol, 22, 6636-47.

FRIEDMACHER, F. \& PURI, P. 2013. Hirschsprung's disease associated with Down syndrome: a meta-analysis of incidence, functional outcomes and mortality. Pediatr Surg Int, 29, 937-46.

FUENTES, J. J., GENESCÀ, L., KINGSBURY, T. J., CUNNINGHAM, K. W., PÉREZ-RIBA, M., ESTIVILL, X. \& DE LA LUNA, S. 2000. DSCR1, overexpressed in Down syndrome, is an inhibitor of calcineurin-mediated signaling pathways. Hum Mol Genet, 9, 1681-90.

GALANTE, M., JANI, H., VANES, L., DANIEL, H., FISHER, E. M. C., TYBULEWICZ, V. L. J., BLISS, T. V. P. \& MORICE, E. 2009. Impairments in motor coordination without major changes in cerebellar plasticity in the Tc1 mouse model of Down syndrome. Hum Mol Genet, $18,1449-1463$.

GARCÍA-CERRO, S., MARTíNEZ, P., VIDAL, V., CORRALES, A., FLÓREZ, J., VIDAL, R., RUEDA, N., ARBONÉS, M. L. \& MARTíNEZ-CUÉ, C. 2014. Overexpression of Dyrk1A is implicated in several cognitive, electrophysiological and neuromorphological alterations found in a mouse model of Down syndrome. PLoS One, 9, e106572.

GARCíA-CERRO, S., RUEDA, N., VIDAL, V., LANTIGUA, S. \& MARTínEZ-CUÉ, C. 2017. Normalizing the gene dosage of Dyrk1A in a mouse model of Down syndrome rescues several Alzheimer's disease phenotypes. Neurobiol Dis, 106, 76-88.

GHOSAL, K., VOGT, D. L., LIANG, M., SHEN, Y., LAMB, B. T. \& PIMPLIKAR, S. W. 2009. Alzheimer's disease-like pathological features in transgenic mice expressing the APP intracellular domain. Proc Natl Acad Sci U S A, 106, 18367-72.

GIBBS, R. A., WEINSTOCK, G. M., METZKER, M. L., MUZNY, D. M., SODERGREN, E. J., SCHERER, S., SCOTT, G., STEFFEN, D., WORLEY, K. C., BURCH, P. E., OKWUONU, G., HINES, S., LEWIS, L., DERAMO, C., DELGADO, O., DUGAN-ROCHA, S., MINER, G., MORGAN, M., HAWES, A., GILL, R., CELERA, HOLT, R. A., ADAMS, M. D., AMANATIDES, P. G., BADEN-TILLSON, H., BARNSTEAD, M., CHIN, S., EVANS, C. A., FERRIERA, S., FOSLER, C., GLODEK, A., GU, Z., JENNINGS, D., KRAFT, C. L., NGUYEN, T., PFANNKOCH, C. M., SITTER, C., SUTTON, G. G., VENTER, J. C., WOODAGE, T., SMITH, D., LEE, H. M., GUSTAFSON, E., CAHILL, P., KANA, A., DOUCETTE-STAMM, L., WEINSTOCK, K., FECHTEL, K., WEISS, R. B., DUNN, D. M., GREEN, E. D., BLAKESLEY, R. W., BOUFFARD, G. G., DE JONG, P. J., OSOEGAWA, K., ZHU, B., MARRA, M., SCHEIN, J., BOSDET, I., FJELL, C., JONES, S., KRZYWINSKI, M., MATHEWSON, C., SIDDIQUI, A., WYE, N., MCPHERSON, J., ZHAO, S., FRASER, C. M., SHETTY, J., SHATSMAN, S., GEER, K., CHEN, Y., ABRAMZON, S., NIERMAN, W. C., HAVLAK, P. H., CHEN, R., DURBIN, K. J., EGAN, A., REN, Y., SONG, X. Z., LI, B., LIU, Y., QIN, X., CAWLEY, S., COONEY, A. J., D'SOUZA, L. M., MARTIN, K., WU, J. Q., GONZALEZ-GARAY, M. L., JACKSON, A. R., KALAFUS, K. J., MCLEOD, M. P., MILOSAVLJEVIC, A., VIRK, D., VOLKOV, A., WHEELER, 
D. A., ZHANG, Z., BAILEY, J. A., EICHLER, E. E., TUZUN, E., et al. 2004. Genome sequence of the Brown Norway rat yields insights into mammalian evolution. Nature, 428, 493-521.

GIORGIO, E., ROBYR, D., SPIELMANN, M., FERRERO, E., DI GREGORIO, E., IMPERIALE, D., VAULA, G., STAMOULIS, G., SANTONI, F., ATZORI, C., GASPARINI, L., FERRERA, D., CANALE, C., GUIPPONI, M., PENNACCHIO, L. A., ANTONARAKIS, S. E., BRUSSINO, A. \& BRUSCO, A. 2015. A large genomic deletion leads to enhancer adoption by the lamin B1 gene: a second path to autosomal dominant adult-onset demyelinating leukodystrophy (ADLD). Hum Mol Genet, 24, 3143-54.

GIRALDO, P. \& MONTOLIU, L. 2001. Size matters: use of YACs, BACs and PACs in transgenic animals. Transgenic Res, 10, 83-103.

GITTON, Y., DAHMANE, N., BAIK, S., RUIZ I ALTABA, A., NEIDHARDT, L., SCHOLZE, M., HERRMANN, B. G., KAHLEM, P., BENKAHLA, A., SCHRINNER, S., YILDIRIMMAN, R., HERWIG, R., LEHRACH, H., YASPO, M. L. \& INITIATIVE, H. E. M. 2002. A gene expression map of human chromosome 21 orthologues in the mouse. Nature, 420, 586-90.

GOODLIFFE, J. W., OLMOS-SERRANO, J. L., AZIZ, N. M., PENNINGS, J. L., GUEDJ, F., BIANCHI, D. W. \& HAYDAR, T. F. 2016. Absence of Prenatal Forebrain Defects in the Dp(16)1Yey/+ Mouse Model of Down Syndrome. J Neurosci, 36, 2926-44.

GORDON, J. W. \& RUDDLE, F. H. 1981. Integration and stable germ line transmission of genes injected into mouse pronuclei. Science, 214, 1244-6.

GRIBBLE, S. M., WISEMAN, F. K., CLAYTON, S., PRIGMORE, E., LANGLEY, E., YANG, F., MAGUIRE, S., FU, B., RAJAN, D., SHEPPARD, O., SCOTT, C., HAUSER, H., STEPHENS, P. J., STEBBingS, L. A., NG, B. L., FITZGERALD, T., QUAIL, M. A., BANERJEE, R., ROTHKAMM, K., TYBULEWICZ, V. L., FISHER, E. M. \& CARTER, N. P. 2013. Massively parallel sequencing reveals the complex structure of an irradiated human chromosome on a mouse background in the Tc1 model of Down syndrome. PLoS One, 8, e60482.

GROEN, H., BOUMAN, K., PIERINI, A., RANKIN, J., RISSMANN, A., HAEUSLER, M., YEVTUSHOK, L., LOANE, M., ERWICH, J. J. H. M. \& DE WALLE, H. E. K. 2017. Stillbirth and neonatal mortality in pregnancies complicated by major congenital anomalies: Findings from a large European cohort. Prenat Diagn, 37, 1100-1111.

GUEDJ, F., PENNINGS, J. L., MASSINGHAM, L. J., WICK, H. C., SIEGEL, A. E., TANTRAVAHI, U. \& BIANCHI, D. W. 2016. An Integrated Human/Murine Transcriptome and Pathway Approach To Identify Prenatal Treatments For Down Syndrome. Sci Rep, 6, 32353.

GUEDJ, F., PENNINGS, J. L., WICK, H. C. \& BIANCHI, D. W. 2015. Analysis of adult cerebral cortex and hippocampus transcriptomes reveals unique molecular changes in the Ts1Cje mouse model of down syndrome. Brain Pathol, 25, 11-23.

GUEDJ, F., PEREIRA, P. L., NAJAS, S., BARALLOBRE, M. J., CHABERT, C., SOUCHET, B., SEBRIE, C., VERNEY, C., HERAULT, Y., ARBONES, M. \& DELABAR, J. M. 2012. DYRK1A: a master regulatory protein controlling brain growth. Neurobiol Dis, 46, 190-203.

GUEDJ, F., SÉBRIÉ, C., RIVALS, I., LEDRU, A., PALY, E., BIZOT, J. C., SMITH, D., RUBIN, E., GILLET, B., ARBONES, M. \& DELABAR, J. M. 2009. Green tea polyphenols rescue of brain defects induced by overexpression of DYRK1A. PLoS One, 4, e4606.

GUIHARD-COSTA, A. M., KHUNG, S., DELBECQUE, K., MENEZ, F. \& DELEZOIDE, A. L. 2006. Biometry of face and brain in fetuses with trisomy 21. Pediatr Res, 59, 33-8. 
HAAS, M. A., BELL, D., SLENDER, A., LANA-ELOLA, E., WATSON-SCALES, S., FISHER, E. M., TYBULEWICZ, V. L. \& GUILLEMOT, F. 2013. Alterations to dendritic spine morphology, but not dendrite patterning, of cortical projection neurons in Tc1 and Ts1Rhr mouse models of Down syndrome. PLoS One, 8, e78561.

HAMILTON, S. M., GREEN, J. R., VEERARAGAVAN, S., YUVA, L., MCCOY, A., WU, Y., WARREN, J., LITTLE, L., JI, D., CUI, X., WEINSTEIN, E. \& PAYLOR, R. 2014. Fmr1 and NIgn3 knockout rats: novel tools for investigating autism spectrum disorders. Behav Neurosci, 128, 103-9.

HAN, X., WANG, R., ZHOU, Y., FEI, L., SUN, H., LAI, S., SAADATPOUR, A., ZHOU, Z., CHEN, H., YE, F., HUANG, D., XU, Y., HUANG, W., JIANG, M., JIANG, X., MAO, J., CHEN, Y., LU, C., XIE, J., FANG, Q., WANG, Y., YUE, R., LI, T., HUANG, H., ORKIN, S. H., YUAN, G. C., CHEN, M. \& GUO, G. 2018. Mapping the Mouse Cell Atlas by Microwell-Seq. Cell, 173, 1307.

HARBOM, L. J., CHRONISTER, W. D. \& MCCONNELL, M. J. 2016. Single neuron transcriptome analysis can reveal more than cell type classification: Does it matter if every neuron is unique? Bioessays, 38, 157-61.

HATTORI, M., FUJIYAMA, A., TAYLOR, T. D., WATANABE, H., YADA, T., PARK, H. S., TOYODA, A., ISHII, K., TOTOKI, Y., CHOI, D. K., GRONER, Y., SOEDA, E., OHKI, M., TAKAGI, T., SAKAKI, Y., TAUDIEN, S., BLECHSCHMIDT, K., POLLEY, A., MENZEL, U., DELABAR, J., KUMPF, K., LEHMANN, R., PATTERSON, D., REICHWALD, K., RUMP, A., SCHILLHABEL, M., SCHUDY, A., ZIMMERMANN, W., ROSENTHAL, A., KUDOH, J., SCHIBUYA, K., KAWASAKI, K., ASAKAWA, S., SHINTANI, A., SASAKI, T., NAGAMINE, K., MITSUYAMA, S., ANTONARAKIS, S. E., MINOSHIMA, S., SHIMIZU, N., NORDSIEK, G., HORNISCHER, K., BRANT, P., SCHARFE, M., SCHON, O., DESARIO, A., REICHELT, J., KAUER, G., BLOCKER, H., RAMSER, J., BECK, A., KLAGES, S., HENNIG, S., RIESSELMANN, L., DAGAND, E., HAAF, T., WEHRMEYER, S., BORZYM, K., GARDINER, K., NIZETIC, D., FRANCIS, F., LEHRACH, H., REINHARDT, R., YASPO, M. L. \& CONSORTIUM, C. M. A. S. 2000. The DNA sequence of human chromosome 21. Nature, 405, 311-9.

HAXBY, J. V. 1989. Neuropsychological evaluation of adults with Down's syndrome: patterns of selective impairment in non-demented old adults. J Ment Defic Res, 33 ( Pt 3), 193210.

HEAD, E., LOTT, I. T., WILCOCK, D. M. \& LEMERE, C. A. 2015. Aging in Down Syndrome and the Development of Alzheimer's Disease Neuropathology. Current Alzheimer Research, 13, 18-29.

HEINTZ, N. 2004. Gene expression nervous system atlas (GENSAT). Nat Neurosci, 7, 483.

HEISE, I., FISHER, S. P., BANKS, G. T., WELLS, S., PEIRSON, S. N., FOSTER, R. G. \& NOLAN, P. M. 2015. Sleep-like behavior and 24-h rhythm disruption in the Tc1 mouse model of Down syndrome. Genes Brain Behav, 14, 209-16.

HERAULT, Y., DELABAR, J. M., FISHER, E. M. C., TYBULEWICZ, V. L. J., YU, E. \& BRAULT, V. 2017. Rodent models in Down syndrome research: impact and future opportunities. Dis Model Mech, 10, 1165-1186.

HERAULT, Y., DUCHON, A., VELOT, E., MARÉCHAL, D. \& BRAULT, V. 2012. The in vivo Down syndrome genomic library in mouse. Prog Brain Res, 197, 169-97.

HERAULT, Y., RASSOULZADEGAN, M., CUZIN, F. \& DUBOULE, D. 1998. Engineering chromosomes in mice through targeted meiotic recombination (TAMERE). Nat Genet, 20, 381-4. 
HILL, C. A., REEVES, R. H. \& RICHTSMEIER, J. T. 2007. Effects of aneuploidy on skull growth in a mouse model of Down syndrome. J Anat, 210, 394-405.

HNISZ, D., DAY, D. S. \& YOUNG, R. A. 2016. Insulated Neighborhoods: Structural and Functional Units of Mammalian Gene Control. Cell, 167, 1188-1200.

HOEFFER, C. A., DEY, A., SACHAN, N., WONG, H., PATTERSON, R. J., SHELTON, J. M., RICHARDSON, J. A., KLANN, E. \& ROTHERMEL, B. A. 2007. The Down syndrome critical region protein RCAN1 regulates long-term potentiation and memory via inhibition of phosphatase signaling. J Neurosci, 27, 13161-72.

HONG, S. \& KIM, D. 2017. Computational characterization of chromatin domain boundaryassociated genomic elements. Nucleic Acids Res, 45, 10403-10414.

HOWE, K., CLARK, M. D., TORROJA, C. F., TORRANCE, J., BERTHELOT, C., MUFFATO, M., COLLINS, J. E., HUMPHRAY, S., MCLAREN, K., MATTHEWS, L., MCLAREN, S., SEALY, I., CACCAMO, M., CHURCHER, C., SCOTT, C., BARRETT, J. C., KOCH, R., RAUCH, G.-J., WHITE, S., CHOW, W., KILIAN, B., QUINTAIS, L. T., GUERRA-ASSUNÇÃO, J. A., ZHOU, Y., GU, Y., YEN, J., VOGEL, J.-H., EYRE, T., REDMOND, S., BANERJEE, R., CHI, J., FU, B., LANGLEY, E., MAGUIRE, S. F., LAIRD, G. K., LLOYD, D., KENYON, E., DONALDSON, S., SEHRA, H., ALMEIDA-KING, J., LOVELAND, J., TREVANION, S., JONES, M., QUAIL, M., WILLEY, D., HUNT, A., BURTON, J., SIMS, S., MCLAY, K., PLUMB, B., DAVIS, J., CLEE, C., OLIVER, K., CLARK, R., RIDDLE, C., ELLIOTT, D., THREADGOLD, G., HARDEN, G., WARE, D., BEGUM, S., MORTIMORE, B., KERRY, G., HEATH, P., PHILLIMORE, B., TRACEY, A., CORBY, N., DUNN, M., JOHNSON, C., WOOD, J., CLARK, S., PELAN, S., GRIFFITHS, G., SMITH, M., GLITHERO, R., HOWDEN, P., BARKER, N., LLOYD, C., STEVENS, C., HARLEY, J., HOLT, K., PANAGIOTIDIS, G., LOVELL, J., BEASLEY, H., HENDERSON, C., GORDON, D., AUGER, K., WRIGHT, D., COLLINS, J., RAISEN, C., DYER, L., LEUNG, K., ROBERTSON, L., AMBRIDGE, K., LEONGAMORNLERT, D., MCGUIRE, S., GILDERTHORP, R., GRIFFITHS, C., MANTHRAVADI, D., NICHOL, S., BARKER, G., et al. 2013. The zebrafish reference genome sequence and its relationship to the human genome. Nature, 496, 498.

HU, L. F., LU, M., HON WONG, P. T. \& BIAN, J. S. 2011. Hydrogen sulfide: neurophysiology and neuropathology. Antioxid Redox Signal, 15, 405-19.

HUGHES, R. N. 2004. The value of spontaneous alternation behavior (SAB) as a test of retention in pharmacological investigations of memory. Neurosci Biobehav Rev, 28, 497-505.

HÄMMERLE, B., ULIN, E., GUIMERA, J., BECKER, W., GUILLEMOT, F. \& TEJEDOR, F. J. 2011. Transient expression of Mnb/Dyrk1a couples cell cycle exit and differentiation of neuronal precursors by inducing p27KIP1 expression and suppressing NOTCH signaling. Development, 138, 2543-54.

IRAQI, F. A., MAHAJNE, M., SALAYMAH, Y., SANDOVSKI, H., TAYEM, H., VERED, K., BALMER, L., HALL, M., MANSHIP, G., MORAHAN, G., PETTIT, K., SCHOLTEN, J., TWEEDIE, K., WALLACE, A., WEERASEKERA, L., CLEAK, J., DURRANT, C., GOODSTADT, L., MOTT, R., YALCIN, B., AYLOR, D. L., BARIC, R. S., BELL, T. A., BENDT, K. M., BRENNAN, J., BROOKS, J. D., BUUS, R. J., CROWLEY, J. J., CALAWAY, J. D., CALAWAY, M. E., CHOLKA, A., DARR, D. B., DIDION, J. P., DORMAN, A., EVERETT, E. T., FERRIS, M. T., MATHES, W. F., FU, C.-P., GOOCH, T. J., GOODSON, S. G., GRALINSKI, L. E., HANSEN, S. D., HEISE, M. T., HOEL, J., HUA, K., KAPITA, M. C., LEE, S., LENARCIC, A. B., LIU, E. Y., LIU, H., MCMILLAN, L., MAGNUSON, T. R., MANLY, K. F., MILLER, D. R., O'BRIEN, D. A., ODET, F., PAKATCl, I. K., PAN, W., DE VILLENA, F. P.-M., PEROU, C. M., POMP, D., QUACKENBUSH, C. R., ROBINSON, N. N., SHARPLESS, N. E., SHAW, G. D., SPENCE, J. S., 
SULLIVAN, P. F., SUN, W., TARANTINO, L. M., VALDAR, W., WANG, J., WANG, W., WELSH, C. E., WHITMORE, A., WILTSHIRE, T., WRIGHT, F. A., XIE, Y., YUN, Z., ZHABOTYNSKY, V., ZHANG, Z., ZOU, F., POWELL, C., STEIGERWALT, J., THREADGILL, D. W., CHESLER, E. J., CHURCHILL, G. A., GATTI, D. M., KORSTANJE, R., SVENSON, K. L., COLLINS, F. S., CRAWFORD, N., HUNTER, K., KELADA, S. N. P., PECK, B. C. E., REILLY, K., TAVAREZ, U., BOTTOMLY, D., HITZEMAN, R., MCWEENEY, S. K., FRELINGER, J., et al. 2012. The Genome Architecture of the Collaborative Cross Mouse Genetic Reference Population. Genetics, 190, 389-U159.

IZZO, A., MANCO, R., BONFIGLIO, F., CALÌ, G., DE CRISTOFARO, T., PATERGNANI, S., CICATIELLO, R., SCRIMA, R., ZANNINI, M., PINTON, P., CONTI, A. \& NITSCH, L. 2014. NRIP1/RIP140 siRNA-mediated attenuation counteracts mitochondrial dysfunction in Down syndrome. Hum Mol Genet, 23, 4406-19.

IZZO, A., NITTI, M., MOLLO, N., PALADINO, S., PROCACCINI, C., FAICCHIA, D., CALÌ, G., GENESIO, R., BONFIGLIO, F., CICATIELLO, R., POLISHCHUK, E., POLISHCHUK, R., PINTON, P., MATARESE, G., CONTI, A. \& NITSCH, L. 2017. Metformin restores the mitochondrial network and reverses mitochondrial dysfunction in Down syndrome cells. Hum Mol Genet, 26, 1056-1069.

JI, X., DADON, D. B., POWELL, B. E., FAN, Z. P., BORGES-RIVERA, D., SHACHAR, S., WEINTRAUB, A. S., HNISZ, D., PEGORARO, G., LEE, T. I., MISTELI, T., JAENISCH, R. \& YOUNG, R. A. 2016. 3D Chromosome Regulatory Landscape of Human Pluripotent Cells. Cell Stem Cell, 18, 262-75.

JIANG, X., LIU, C., YU, T., ZHANG, L., MENG, K., XING, Z., BELICHENKO, P. V., KLESCHEVNIKOV, A. M., PAO, A., PERESIE, J., WIE, S., MOBLEY, W. C. \& YU, Y. E. 2015. Genetic dissection of the Down syndrome critical region. Hum Mol Genet.

KACZMARSKI, W., BARUA, M., MAZUR-KOLECKA, B., FRACKOWIAK, J., DOWJAT, W., MEHTA, P., BOLTON, D., HWANG, Y. W., RABE, A., ALBERTINI, G. \& WEGIEL, J. 2014. Intracellular distribution of differentially phosphorylated dual-specificity tyrosine phosphorylation-regulated kinase 1A (DYRK1A). J Neurosci Res, 92, 162-73.

KAHLEM, P., SULTAN, M., HERWIG, R., STEINFATH, M., BALZEREIT, D., EPPENS, B., SARAN, N. G., PLETCHER, M. T., SOUTH, S. T., STETTEN, G., LEHRACH, H., REEVES, R. H. \& YASPO, M. L. 2004. Transcript level alterations reflect gene dosage effects across multiple tissues in a mouse model of down syndrome. Genome Res, 14, 1258-67.

KAZEMI, M., SALEHI, M. \& KHEIROLLAHI, M. 2016. Down Syndrome: Current Status, Challenges and Future Perspectives. Int J Mol Cell Med, 5, 125-133.

KECK-WHERLEY, J., GROVER, D., BHATTACHARYYA, S., XU, X., HOLMAN, D., LOMBARDINI, E. D., VERMA, R., BISWAS, R. \& GALDZICKI, Z. 2011. Abnormal microRNA expression in Ts65Dn hippocampus and whole blood: contributions to Down syndrome phenotypes. Dev Neurosci, 33, 451-67.

KELLY, P. A. \& RAHMANI, Z. 2005. DYRK1A enhances the mitogen-activated protein kinase cascade in PC12 cells by forming a complex with Ras, B-Raf, and MEK1. Mol Biol Cell, 16, 3562-73.

KLESCHEVNIKOV, A. M., BELICHENKO, P. V., VILLAR, A. J., EPSTEIN, C. J., MALENKA, R. C. \& MOBLEY, W. C. 2004. Hippocampal long-term potentiation suppressed by increased inhibition in the Ts65Dn mouse, a genetic model of Down syndrome. J Neurosci, 24, 8153-60.

KLESCHEVNIKOV, A. M., YU, J., KIM, J., LYSENKO, L. V., ZENG, Z., YU, Y. E. \& MOBLEY, W. C. 2017. Evidence that increased Kcnj6 gene dose is necessary for deficits in behavior 
and dentate gyrus synaptic plasticity in the Ts65Dn mouse model of Down syndrome. Neurobiol Dis, 103, 1-10.

KORBEL, J. O., TIROSH-WAGNER, T., URBAN, A. E., CHEN, X. N., KASOWSKI, M., DAI, L., GRUBERT, F., ERDMAN, C., GAO, M. C., LANGE, K., SOBEL, E. M., BARLOW, G. M., AYLSWORTH, A. S., CARPENTER, N. J., CLARK, R. D., COHEN, M. Y., DORAN, E., FALIKZACCAI, T., LEWIN, S. O., LOTT, I. T., MCGILLIVRAY, B. C., MOESCHLER, J. B., PETTENATI, M. J., PUESCHEL, S. M., RAO, K. W., SHAFFER, L. G., SHOHAT, M., VAN RIPER, A. J., WARBURTON, D., WEISSMAN, S., GERSTEIN, M. B., SNYDER, M. \& KORENBERG, J. R. 2009. The genetic architecture of Down syndrome phenotypes revealed by high-resolution analysis of human segmental trisomies. Proc Natl Acad Sci U S A, 106, 12031-6.

KORENBERG, J. R., BRADLEY, C. \& DISTECHE, C. M. 1992. Down syndrome: molecular mapping of the congenital heart disease and duodenal stenosis. Am J Hum Genet, 50, 294-302.

KORENBERG, J. R., CHEN, X. N., SCHIPPER, R., SUN, Z., GONSKY, R., GERWEHR, S., CARPENTER, N., DAUMER, C., DIGNAN, P. \& DISTECHE, C. 1994. Down syndrome phenotypes: the consequences of chromosomal imbalance. Proc Natl Acad Sci U S A, 91, 4997-5001.

KREFTING, J., ANDRADE-NAVARRO, M. A. \& IBN-SALEM, J. 2018. Evolutionary stability of topologically associating domains is associated with conserved gene regulation. $B M C$ Biol, 16, 87.

KURABAYASHI, N. \& SANADA, K. 2013. Increased dosage of DYRK1A and DSCR1 delays neuronal differentiation in neocortical progenitor cells. Genes Dev, 27, 2708-21.

KURT, M. A., DAVIES, D. C., KIDD, M., DIERSSEN, M. \& FLOREZ, J. 2000. Synaptic deficit in the temporal cortex of partial trisomy 16 (Ts65Dn) mice. Brain Res, 858, 191-7.

LAFFAIRE, J., RIVALS, I., DAUPHINOT, L., PASTEAU, F., WEHRLE, R., LARRAT, B., VITALIS, T., MOLDRICH, R., ROSSIER, J., SINKUS, R., HERAULT, Y., DUSART, I. \& POTIER, M. 2009. Gene expression signature of cerebellar hypoplasia in a mouse model of Down syndrome during postnatal development. BMC Genomics, 10, 138.

LAMB, B. T., SISODIA, S. S., LAWLER, A. M., SLUNT, H. H., KITT, C. A., KEARNS, W. G., PEARSON, P. L., PRICE, D. L. \& GEARHART, J. D. 1993a. Introduction and expression of the 400 kilobase amyloid precursor protein gene in transgenic mice [corrected]. Nat Genet, 5, 22-30.

LAMB, B. T., SISODIA, S. S., LAWLER, A. M., SLUNT, H. H., KITT, C. A., KEARNS, W. G., PEARSON, P. L., PRICE, D. L. \& GEARHART, J. D. 1993b. INTRODUCTION AND EXPRESSION OF THE 400 KILOBASE PRECURSOR AMYLOID PROTEIN GENE IN TRANSGENIC MICE. Nature Genetics, 5, 22-29.

LANA-ELOLA, E., WATSON-SCALES, S., SLENDER, A., GIBBINS, D., MARTINEAU, A., DOUGLAS, C., MOHUN, T., FISHER, E. M. \& TYBULEWICZ, V. L. J. 2016. Genetic dissection of Down syndrome-associated congenital heart defects using a new mouse mapping panel. Elife, 5.

LANGE, B. 2000. The management of neoplastic disorders of haematopoiesis in children with Down's syndrome. Br J Haematol, 110, 512-24.

LEE, M. S., KAO, S. C., LEMERE, C. A., XIA, W., TSENG, H. C., ZHOU, Y., NEVE, R., AHLIJANIAN, M. K. \& TSAI, L. H. 2003. APP processing is regulated by cytoplasmic phosphorylation. J Cell Biol, 163, 83-95. 
LEIN, E. S., HAWRYLYCZ, M. J., AO, N., AYRES, M., BENSINGER, A., BERNARD, A., BOE, A. F., BOGUSKI, M. S., BROCKWAY, K. S., BYRNES, E. J., CHEN, L., CHEN, T. M., CHIN, M. C., CHONG, J., CROOK, B. E., CZAPLINSKA, A., DANG, C. N., DATTA, S., DEE, N. R., DESAKI, A. L., DESTA, T., DIEP, E., DOlBEARE, T. A., DONELAN, M. J., DONG, H. W., DOUGHERTY, J. G., DUNCAN, B. J., EBBERT, A. J., EICHELE, G., ESTIN, L. K., FABER, C., FACER, B. A., FIELDS, R., FISCHER, S. R., FLISS, T. P., FRENSLEY, C., GATES, S. N., GLATTFELDER, K. J., HALVERSON, K. R., HART, M. R., HOHMANN, J. G., HOWELL, M. P., JEUNG, D. P., JOHNSON, R. A., KARR, P. T., KAWAL, R., KIDNEY, J. M., KNAPIK, R. H., KUAN, C. L., LAKE, J. H., LARAMEE, A. R., LARSEN, K. D., LAU, C., LEMON, T. A., LIANG, A. J., LIU, Y., LUONG, L. T., MICHAELS, J., MORGAN, J. J., MORGAN, R. J., MORTRUD, M. T., MOSQUEDA, N. F., NG, L. L., NG, R., ORTA, G. J., OVERLY, C. C., PAK, T. H., PARRY, S. E., PATHAK, S. D., PEARSON, O. C., PUCHALSKI, R. B., RILEY, Z. L., ROCKETT, H. R., ROWLAND, S. A., ROYALL, J. J., RUIZ, M. J., SARNO, N. R., SCHAFFNIT, K., SHAPOVALOVA, N. V., SIVISAY, T., SLAUGHTERBECK, C. R., SMITH, S. C., SMITH, K. A., SMITH, B. I., SODT, A. J., STEWART, N. N., STUMPF, K. R., SUNKIN, S. M., SUTRAM, M., TAM, A., TEEMER, C. D., THALLER, C., THOMPSON, C. L., VARNAM, L. R., VISEL, A., WHITLOCK, R. M., WOHNOUTKA, P. E., WOLKEY, C. K., WONG, V. Y., WOOD, M., et al. 2007. Genome-wide atlas of gene expression in the adult mouse brain. Nature, 445, 168-76.

LEPAGNOL-BESTEL, A. M., ZVARA, A., MAUSSION, G., QUIGNON, F., NGIMBOUS, B., RAMOZ, N., IMBEAUD, S., LOE-MIE, Y., BENIHOUD, K., AGIER, N., SALIN, P. A., CARDONA, A., KHUNG-SAVATOVSKY, S., KALLUNKI, P., DELABAR, J. M., PUSKAS, L. G., DELACROIX, H., AGGERBECK, L., DELEZOIDE, A. L., DELATTRE, O., GORWOOD, P., MOALIC, J. M. \& SIMONNEAU, M. 2009. DYRK1A interacts with the REST/NRSF-SWI/SNF chromatin remodelling complex to deregulate gene clusters involved in the neuronal phenotypic traits of Down syndrome. Hum Mol Genet, 18, 1405-14.

LI, A., YIN, X., XU, B., WANG, D., HAN, J., WEI, Y., DENG, Y., XIONG, Y. \& ZHANG, Z. 2018. Decoding topologically associating domains with ultra-low resolution $\mathrm{Hi}-\mathrm{C}$ data by graph structural entropy. Nature Communications, 9, 3265.

LI, Z., YU, T., MORISHIMA, M., PAO, A., LADUCA, J., CONROY, J., NOWAK, N., MATSUI, S., SHIRAISHI, I. \& YU, Y. E. 2007. Duplication of the entire 22.9 Mb human chromosome 21 syntenic region on mouse chromosome 16 causes cardiovascular and gastrointestinal abnormalities. Hum Mol Genet, 16, 1359-66.

LIGNON, J. M., BICHLER, Z., HIVERT, B., GANNIER, F. E., COSNAY, P., DEL RIO, J. A., MIGLIORESAMOUR, D. \& MALÉCOT, C. O. 2008. Altered heart rate control in transgenic mice carrying the KCNJ6 gene of the human chromosome 21. Physiol Genomics, 33, 230-9.

LIU, C., MORISHIMA, M., JIANG, X., YU, T., MENG, K., RAY, D., PAO, A., YE, P., PARMACEK, M. S. \& YU, Y. E. 2014. Engineered chromosome-based genetic mapping establishes a 3.7 $\mathrm{Mb}$ critical genomic region for Down syndrome-associated heart defects in mice. Hum Genet, 133, 743-53.

LIU, F., LIANG, Z., WEGIEL, J., HWANG, Y. W., IQBAL, K., GRUNDKE-IQBAL, I., RAMAKRISHNA, N. \& GONG, C. X. 2008. Overexpression of Dyrk1A contributes to neurofibrillary degeneration in Down syndrome. FASEB J, 22, 3224-33.

LIU, T., SIMS, D. \& BAUM, B. 2009. Parallel RNAi screens across different cell lines identify generic and cell type-specific regulators of actin organization and cell morphology. Genome Biol, 10, R26. 
LIU, Y., LIN, Z., LIU, M., WANG, H. \& SUN, H. 2017. Overexpression of DYRK1A, a Down Syndrome Candidate gene, Impairs Primordial Germ Cells Maintenance and Migration in zebrafish. Sci Rep, 7, 15313.

LOANE, M., MORRIS, J. K., ADDOR, M. C., ARRIOLA, L., BUDD, J., DORAY, B., GARNE, E., GATT, M., HAEUSLER, M., KHOSHNOOD, B., KLUNGS $\varnothing$ YR MELVE, K., LATOS-BIELENSKA, A., MCDONNELL, B., MULLANEY, C., O'MAHONY, M., QUEISSER-WAHRENDORF, A., RANKIN, J., RISSMANN, A., ROUNDING, C., SALVADOR, J., TUCKER, D., WELLESLEY, D., YEVTUSHOK, L. \& DOLK, H. 2013. Twenty-year trends in the prevalence of Down syndrome and other trisomies in Europe: impact of maternal age and prenatal screening. Eur J Hum Genet, 21, 27-33.

LOCKE, D. P., HILLIER, L. W., WARREN, W. C., WORLEY, K. C., NAZARETH, L. V., MUZNY, D. M., YANG, S.-P., WANG, Z., CHINWALLA, A. T., MINX, P., MITREVA, M., COOK, L., DELEHAUNTY, K. D., FRONICK, C., SCHMIDT, H., FULTON, L. A., FULTON, R. S., NELSON, J. O., MAGRINI, V., POHL, C., GRAVES, T. A., MARKOVIC, C., CREE, A., DINH, H. H., HUME, J., KOVAR, C. L., FOWLER, G. R., LUNTER, G., MEADER, S., HEGER, A., PONTING, C. P., MARQUES-BONET, T., ALKAN, C., CHEN, L., CHENG, Z., KIDD, J. M., EICHLER, E. E., WHITE, S., SEARLE, S., VILELLA, A. J., CHEN, Y., FLICEK, P., MA, J., RANEY, B., SUH, B., BURHANS, R., HERRERO, J., HAUSSLER, D., FARIA, R., FERNANDO, O., DARRÉ, F., FARRÉ, D., GAZAVE, E., OLIVA, M., NAVARRO, A., ROBERTO, R., CAPOZZI, O., ARCHIDIACONO, N., VALLE, G. D., PURGATO, S., ROCCHI, M., KONKEL, M. K., WALKER, J. A., ULLMER, B., BATZER, M. A., SMIT, A. F. A., HUBLEY, R., CASOLA, C., SCHRIDER, D. R., HAHN, M. W., QUESADA, V., PUENTE, X. S., ORDOÑEZ, G. R., LÓPEZ-OTÍN, C., VINAR, T., BREJOVA, B., RATAN, A., HARRIS, R. S., MILLER, W., KOSIOL, C., LAWSON, H. A., TALIWAL, V., MARTINS, A. L., SIEPEL, A., ROYCHOUDHURY, A., MA, X., DEGENHARDT, J., BUSTAMANTE, C. D., GUTENKUNST, R. N., MAILUND, T., DUTHEIL, J. Y., HOBOLTH, A., SCHIERUP, M. H., RYDER, O. A., YOSHINAGA, Y., DE JONG, P. J., WEINSTOCK, G. M., ROGERS, J., MARDIS, E. R., GIBBS, R. A., et al. 2011. Comparative and demographic analysis of orang-utan genomes. Nature, 469, 529.

LOPES PEREIRA, P., MAGNOL, L., SAHÚN, I., BRAULT, V., DUCHON, A., PRANDINI, P., GRUART, A., BIZOT, J., CHADEFAUX-VEKEMANS, B., DEUTSCH, S., TROVERO, F., DELGADOGARCÍA, J., ANTONARAKIS, S., DIERSSEN, M. \& HERAULT, Y. 2009. A new mouse model for the trisomy of the Abcg1-U2af1 region reveals the complexity of the combinatorial genetic code of down syndrome. Hum Mol Genet, 18, 4756-69.

LUJÁN, R., MAYLIE, J. \& ADELMAN, J. P. 2009. New sites of action for GIRK and SK channels. Nat Rev Neurosci, 10, 475-80.

LUKE, S., GANDHI, S. \& VERMA, R. S. 1995. Conservation of the Down syndrome critical region in humans and great apes. Gene, 161, 283-285.

LUPIÁÑEZ, D. G., KRAFT, K., HEINRICH, V., KRAWITZ, P., BRANCATI, F., KLOPOCKI, E., HORN, D., KAYSERILI, H., OPITZ, J. M., LAXOVA, R., SANTOS-SIMARRO, F., GILBERTDUSSARDIER, B., WITTLER, L., BORSCHIWER, M., HAAS, S. A., OSTERWALDER, M., FRANKE, M., TIMMERMANN, B., HECHT, J., SPIELMANN, M., VISEL, A. \& MUNDLOS, S. 2015. Disruptions of topological chromatin domains cause pathogenic rewiring of gene-enhancer interactions. Cell, 161, 1012-1025.

LYLE, R., BÉNA, F., GAGOS, S., GEHRIG, C., LOPEZ, G., SCHINZEL, A., LESPINASSE, J., BOTTANI, A., DAHOUN, S., TAINE, L., DOCO-FENZY, M., CORNILLET-LEFÈBVRE, P., PELET, A., LYONNET, S., TOUTAIN, A., COLLEAUX, L., HORST, J., KENNERKNECHT, I., 
WAKAMATSU, N., DESCARTES, M., FRANKLIN, J., FLORENTIN-ARAR, L., KITSIOU, S., AÏT YAHYA-GRAISON, E., COSTANTINE, M., SINET, P., DELABAR, J. \& ANTONARAKIS, S. 2009. Genotype-phenotype correlations in Down syndrome identified by array CGH in 30 cases of partial trisomy and partial monosomy chromosome 21. Eur J Hum Genet, 17, 454-66.

LÜSCHER, C., JAN, L. Y., STOFFEL, M., MALENKA, R. C. \& NICOLL, R. A. 1997. G proteincoupled inwardly rectifying $\mathrm{K}+$ channels (GIRKs) mediate postsynaptic but not presynaptic transmitter actions in hippocampal neurons. Neuron, 19, 687-95.

M PURSER, H. R. \& JARROLD, C. 2005. Impaired verbal short-term memory in Down syndrome reflects a capacity limitation rather than atypically rapid forgetting. $J$ Exp Child Psychol, 91, 1-23.

MACAULAY, I. C., HAERTY, W., KUMAR, P., LI, Y. I., HU, T. X., TENG, M. J., GOOLAM, M., SAURAT, N., COUPLAND, P., SHIRLEY, L. M., SMITH, M., VAN DER AA, N., BANERJEE, R., ELLIS, P. D., QUAIL, M. A., SWERDLOW, H. P., ZERNICKA-GOETZ, M., LIVESEY, F. J., PONTING, C. P. \& VOET, T. 2015. G\&T-seq: parallel sequencing of single-cell genomes and transcriptomes. Nat Methods, 12, 519-22.

MAGDALENO, S., JENSEN, P., BRUMWELL, C. L., SEAL, A., LEHMAN, K., ASBURY, A., CHEUNG, T., CORNELIUS, T., BATTEN, D. M., EDEN, C., NORLAND, S. M., RICE, D. S., DOSOOYE, N., SHAKYA, S., MEHTA, P. \& CURRAN, T. 2006. BGEM: an in situ hybridization database of gene expression in the embryonic and adult mouse nervous system. PLoS Biol, 4, e86.

MANN, D. M. \& ESIRI, M. M. 1989. The pattern of acquisition of plaques and tangles in the brains of patients under 50 years of age with Down's syndrome. J Neurol Sci, 89, 16979.

MARECHAL, D., BRAULT, V., LEON, A., MARTIN, D., LOPES PEREIRA, P., LOAËC, N., BIRLING, M. C., FRIOCOURT, G., BLONDEL, M. \& HERAULT, Y. 2019a. Cbs overdosage is necessary and sufficient to induce cognitive phenotypes in mouse models of Down syndrome and interacts genetically with Dyrk1a. Hum Mol Genet, 28, 1561-1577.

MARECHAL, D., BRAULT, V., LEON, A., MARTIN, D., PEREIRA, P. L., LOAËC, N., BIRLING, M. C., FRIOCOURT, G., BLONDEL, M. \& HERAULT, Y. 2019b. Cbs overdosage is necessary and sufficient to induce cognitive phenotypes in mouse models of Down syndrome and interacts genetically with Dyrk1a. Hum Mol Genet.

MARECHAL, D., LOPES PEREIRA, P., DUCHON, A. \& HERAULT, Y. 2015. Dosage of the Abcg1U2af1 region modifies locomotor and cognitive deficits observed in the Tc1 mouse model of Down syndrome. PLoS One, 10, e0115302.

MARTIN, K. R., CORLETT, A., DUBACH, D., MUSTAFA, T., COLEMAN, H. A., PARKINGTON, H. C., MERSON, T. D., BOURNE, J. A., PORTA, S., ARBONÉS, M. L., FINKELSTEIN, D. I. \& PRITCHARD, M. A. 2012. Over-expression of RCAN1 causes Down syndrome-like hippocampal deficits that alter learning and memory. Hum Mol Genet, 21, 3025-41.

MARTINEZ DE LAGRAN, M., BENAVIDES-PICCIONE, R., BALLESTEROS-YAÑEZ, I., CALVO, M., MORALES, M., FILLAT, C., DEFELIPE, J., RAMAKERS, G. J. \& DIERSSEN, M. 2012. Dyrk1A influences neuronal morphogenesis through regulation of cytoskeletal dynamics in mammalian cortical neurons. Cereb Cortex, 22, 2867-77.

MARTINEZ-CUE, C., RUEDA, N., GARCIA, E., DAVISSON, M. T., SCHMIDT, C. \& FLOREZ, J. 2005. Behavioral, cognitive and biochemical responses to different environmental conditions in male Ts65Dn mice, a model of Down syndrome. Behav Brain Res, 163, 174-85. 
MCCARRON, M., GILL, M., MCCALLION, P. \& BEGLEY, C. 2005. Health co-morbidities in ageing persons with Down syndrome and Alzheimer's dementia. J Intellect Disabil Res, 49, 560-6.

MCCARRON, M., MCCALLION, P., REILLY, E., DUNNE, P., CARROLL, R. \& MULRYAN, N. 2017. A prospective 20-year longitudinal follow-up of dementia in persons with Down syndrome. J Intellect Disabil Res, 61, 843-852.

MCCARRON, M., MCCALLION, P., REILLY, E. \& MULRYAN, N. 2014. A prospective 14-year longitudinal follow-up of dementia in persons with Down syndrome. J Intellect Disabil Res, 58, 61-70.

MCCLURE, H. M., BELDEN, K. H., PIEPER, W. A. \& JACOBSON, C. B. 1969. Autosomal Trisomy in a Chimpanzee: Resemblance to Down's Syndrome. Science, 165, 1010.

MCCORMICK, M. K., SHERO, J. H., CHEUNG, M. C., KAN, Y. W., HIETER, P. A. \& ANTONARAKIS, S. E. 1989. Construction of human chromosome 21-specific yeast artificial chromosomes. Proc Natl Acad Sci U S A, 86, 9991-5.

MERRIHEW, R. V., MARBURGER, K., PENNINGTON, S. L., ROTH, D. B. \& WILSON, J. H. 1996. High-frequency illegitimate integration of transfected DNA at preintegrated target sites in a mammalian genome. Mol Cell Biol, 16, 10-8.

MOORE, C. S., HAWKINS, C., FRANCA, A., LAWLER, A., DEVENNEY, B., DAS, I. \& REEVES, R. H. 2010. Increased male reproductive success in Ts65Dn "Down syndrome" mice. Mamm Genome, 21, 543-9.

MORI, T., KOYAMA, N., ARENDASH, G. W., HORIKOSHI-SAKURABA, Y., TAN, J. \& TOWN, T. 2010. Overexpression of human S100B exacerbates cerebral amyloidosis and gliosis in the Tg2576 mouse model of Alzheimer's disease. Glia, 58, 300-14.

MORICE, E., ANDREAE, L. C., COOKE, S. F., VANES, L., FISHER, E. M. C., TYBULEWICZ, V. L. J. \& BLISS, T. V. P. 2008. Preservation of long-term memory and synaptic plasticity despite short-term impairments in the Tc1 mouse model of Down syndrome. Learn Mem, 15, 492-500.

MORRIS, J. K., WALD, N. J. \& WATT, H. C. 1999. Fetal loss in Down syndrome pregnancies. Prenat Diagn, 19, 142-5.

MORRIS, R. 1984. DEVELOPMENTS OF A WATER-MAZE PROCEDURE FOR STUDYING SPATIALLEARNING IN THE RAT. Journal of Neuroscience Methods, 11, 47-60.

MOUTON-LIGER, F., SAHÚN, I., COLLIN, T., LOPES PEREIRA, P., MASINI, D., THOMAS, S., PALY, E., LUILIER, S., MÊME, S., JOUHAULT, Q., BENNAÏ, S., BELOEIL, J. C., BIZOT, J. C., HÉRAULT, Y., DIERSSEN, M. \& CRÉAU, N. 2014. Developmental molecular and functional cerebellar alterations induced by PCP4/PEP19 overexpression: implications for Down syndrome. Neurobiol Dis, 63, 92-106.

MOUTON-LIGER, F., THOMAS, S., RATTENBACH, R., MAGNOL, L., LARIGALDIE, V., LEDRU, A., HERAULT, Y., VERNEY, C. \& CRÉAU, N. 2011. PCP4 (PEP19) overexpression induces premature neuronal differentiation associated with $\mathrm{Ca}(2+)$ /calmodulin-dependent kinase II- $\delta$ activation in mouse models of Down syndrome. J Comp Neurol, 519, 2779802.

MOWERY, C. T., REYES, J. M., CABAL-HIERRO, L., HIGBY, K. J., KARLIN, K. L., WANG, J. H., KIMMERLING, R. J., CEJAS, P., LIM, K., LI, H., FURUSAWA, T., LONG, H. W., PELLMAN, D., CHAPUY, B., BUSTIN, M., MANALIS, S. R., WESTBROOK, T. F., LIN, C. Y. \& LANE, A. A. 2018. Trisomy of a Down Syndrome Critical Region Globally Amplifies Transcription via HMGN1 Overexpression. Cell Rep, 25, 1898-1911.e5. 
NADEL, L. 2003. Down's syndrome: a genetic disorder in biobehavioral perspective. Genes Brain Behav, 2, 156-66.

NAJAS, S., ARRANZ, J., LOCHHEAD, P. A., ASHFORD, A. L., OXLEY, D., DELABAR, J. M., COOK, S. J., BARALLOBRE, M. J. \& ARBONÉS, M. L. 2015. DYRK1A-mediated Cyclin D1 Degradation in Neural Stem Cells Contributes to the Neurogenic Cortical Defects in Down Syndrome. EBioMedicine, 2, 120-34.

NARENDRA, V., BULAJIĆ, M., DEKKER, J., MAZZONI, E. O. \& REINBERG, D. 2016. CTCFmediated topological boundaries during development foster appropriate gene regulation. Genes Dev, 30, 2657-2662.

NELSON, D. L. \& GIBBS, R. A. 2004. Genetics. The critical region in trisomy 21. Science, 306, 619-21.

NETZER, W. J., POWELL, C., NONG, Y., BLUNDELL, J., WONG, L., DUFF, K., FLAJOLET, M. \& GREENGARD, P. 2010. Lowering beta-amyloid levels rescues learning and memory in a Down syndrome mouse model. PLoS One, 5, e10943.

NGUYEN, T. L., DUCHON, A., MANOUSOPOULOU, A., LOAËC, N., VILLIERS, B., PANI, G., KARATAS, M., MECHLING, A. E., hARSAN, L. A., LIMANTON, E., BAZUREAU, J. P., CARREAUX, F., GARBIS, S. D., MEIJER, L. \& HERAULT, Y. 2018. Correction of cognitive deficits in mouse models of Down syndrome by a pharmacological inhibitor of DYRK1A. Dis Model Mech, 11.

NIEBUHR, E. 1974. Down's syndrome. The possibility of a pathogenetic segment on chromosome no. 21. Humangenetik, 21, 99-101.

NORDQUIST, S. K., SMITH, S. R. \& PIERCE, J. T. 2018. Systematic Functional Characterization of Human 21st Chromosome Orthologs in. G3 (Bethesda), 8, 967-979.

O'DOHERTY, A., RUF, S., MULLIGAN, C., HILDRETH, V., ERRINGTON, M. L., COOKE, S., SESAY, A., MOdINO, S., VANES, L., HERNANDEZ, D., LINEHAN, J. M., SHARPE, P. T., BRANDNER, S., BLISS, T. V., HENDERSON, D. J., NIZETIC, D., TYBULEWICZ, V. L. \& FISHER, E. M. 2005. An aneuploid mouse strain carrying human chromosome 21 with Down syndrome phenotypes. Science, 309, 2033-7.

OLMOS-SERRANO, J. L., KANG, H. J., TYLER, W. A., SILBEREIS, J. C., CHENG, F., ZHU, Y., PLETIKOS, M., JANKOVIC-RAPAN, L., CRAMER, N. P., GALDZICKI, Z., GOODLIFFE, J., PETERS, A., SETHARES, C., DELALle, I., GOLDEN, J. A., HAYDAR, T. F. \& SESTAN, N. 2016a. Down Syndrome Developmental Brain Transcriptome Reveals Defective Oligodendrocyte Differentiation and Myelination. Neuron, 89, 1208-22.

OLMOS-SERRANO, J. L., TYLER, W. A., CABRAL, H. J. \& HAYDAR, T. F. 2016b. Longitudinal measures of cognition in the Ts65Dn mouse: Refining windows and defining modalities for therapeutic intervention in Down syndrome. Exp Neurol, 279, 40-56.

OLSON, L. E., RICHTSMEIER, J. T., LESZL, J. \& REEVES, R. H. 2004. A chromosome 21 critical region does not cause specific Down syndrome phenotypes. Science, 306, 687-90.

OLSON, L. E., ROPER, R. J., SENGSTAKEN, C. L., PETERSON, E. A., AQUINO, V., GALDZICKI, Z., SIAREY, R., PLETNIKOV, M., MORAN, T. H. \& REEVES, R. H. 2007. Trisomy for the Down syndrome 'critical region' is necessary but not sufficient for brain phenotypes of trisomic mice. Hum Mol Genet, 16, 774-82.

ORI-MCKENNEY, K. M., MCKENNEY, R. J., HUANG, H. H., LI, T., MELTZER, S., JAN, L. Y., VALE, R. D., WIITA, A. P. \& JAN, Y. N. 2016. Phosphorylation of $\beta$-Tubulin by the Down Syndrome Kinase, Minibrain/DYRK1a, Regulates Microtubule Dynamics and Dendrite Morphogenesis. Neuron, 90, 551-63. 
PARK, J. \& CHUNG, K. C. 2013. New Perspectives of Dyrk1A Role in Neurogenesis and Neuropathologic Features of Down Syndrome. Exp Neurobiol, 22, 244-8.

PARK, J., OH, Y., YOO, L., JUNG, M. S., SONG, W. J., LEE, S. H., SEO, H. \& CHUNG, K. C. 2010. Dyrk1A phosphorylates $\mathrm{p} 53$ and inhibits proliferation of embryonic neuronal cells. $J$ Biol Chem, 285, 31895-906.

PARK, J., SUNG, J. Y., SONG, W. J., CHANG, S. \& CHUNG, K. C. 2012. Dyrk1A negatively regulates the actin cytoskeleton through threonine phosphorylation of N-WASP. J Cell Sci, 125, 67-80.

PARRA, V., ALTAMIRANO, F., HERNÁNDEZ-FUENTES, C. P., TONG, D., KYRYCHENKO, V., ROTTER, D., PEDROZO, Z., HILL, J. A., EISNER, V., LAVANDERO, S., SCHNEIDER, J. W. \& ROTHERMEL, B. A. 2018. Down Syndrome Critical Region 1 Gene,. Circ Res, 122, e20e33.

PATEL, A., YAMASHITA, N., ASCAÑO, M., BODMER, D., BOEHM, E., BODKIN-CLARKE, C., RYU, Y. K. \& KURUVILLA, R. 2015. RCAN1 links impaired neurotrophin trafficking to aberrant development of the sympathetic nervous system in Down syndrome. Nat Commun, 6, 10119.

PATHAK, A., ROHILLA, A., GUPTA, T., AKHTAR, M. J., HAIDER, M. R., SHARMA, K., HAIDER, K. \& YAR, M. S. 2018. DYRK1A kinase inhibition with emphasis on neurodegeneration: A comprehensive evolution story-cum-perspective. Eur J Med Chem, 158, 559-592.

PELLERI, M. C., CATTANI, C., VITALE, L., ANTONAROS, F., STRIPPOLI, P., LOCATELLI, C., COCCHI, G., PIOVESAN, A. \& CARACAUSI, M. 2018. Integrated Quantitative Transcriptome Maps of Human Trisomy 21 Tissues and Cells. Front Genet, 9, 125.

PENNINGTON, B. F., MOON, J., EDGIN, J., STEDRON, J. \& NADEL, L. 2003. The neuropsychology of Down syndrome: evidence for hippocampal dysfunction. Child Dev, 74, 75-93.

Perluigl, M., PUPO, G., tRAMUtola, A., CINI, C., COCCIA, R., BARONE, E., heAD, E., BUTTERFIELD, D. A. \& DI DOMENICO, F. 2014. Neuropathological role of $\mathrm{PI3K} / \mathrm{Akt} / \mathrm{mTOR}$ axis in Down syndrome brain. Biochim Biophys Acta, 1842, 1144-53.

PHILLIPS-CREMINS, J. E., SAURIA, M. E., SANYAL, A., GERASIMOVA, T. I., LAJOIE, B. R., BELL, J. S., ONG, C. T., HOOKWAY, T. A., GUO, C., SUN, Y., BLAND, M. J., WAGSTAFF, W., DALTON, S., MCDEVITT, T. C., SEN, R., DEKKER, J., TAYLOR, J. \& CORCES, V. G. 2013. Architectural protein subclasses shape 3D organization of genomes during lineage commitment. Cell, 153, 1281-95.

PICCOLI, C., IZZO, A., SCRIMA, R., BONFIGLIO, F., MANCO, R., NEGRI, R., QUARATO, G., CELA, O., RIPOLI, M., PRISCO, M., GENTILE, F., CALÌ, G., PINTON, P., CONTI, A., NITSCH, L. \& CAPITANIO, N. 2013. Chronic pro-oxidative state and mitochondrial dysfunctions are more pronounced in fibroblasts from Down syndrome foeti with congenital heart defects. Hum Mol Genet, 22, 1218-32.

PINTER, J. D., ELIEZ, S., SCHMITT, J. E., CAPONE, G. T. \& REISS, A. L. 2001. Neuroanatomy of Down's syndrome: a high-resolution MRI study. Am J Psychiatry, 158, 1659-65.

POPE, B. D., RYBA, T., DILEEP, V., YUE, F., WU, W., DENAS, O., VERA, D. L., WANG, Y., HANSEN, R. S., CANFIELD, T. K., THURMAN, R. E., CHENG, Y., GÜLSOY, G., DENNIS, J. H., SNYDER, M. P., STAMATOYANNOPOULOS, J. A., TAYLOR, J., HARDISON, R. C., KAHVECI, T., REN, B. \& GILBERT, D. M. 2014. Topologically associating domains are stable units of replication-timing regulation. Nature, 515, 402-5.

PÉREZ-NÚÑEZ, R., BARRAZA, N., GONZALEZ-JAMETT, A., CÁRDENAS, A. M., BARNIER, J. V. \& CAVIEDES, P. 2016. Overexpressed Down Syndrome Cell Adhesion Molecule (DSCAM) 
Deregulates P21-Activated Kinase (PAK) Activity in an In Vitro Neuronal Model of Down Syndrome: Consequences on Cell Process Formation and Extension. Neurotox Res, 30, 76-87.

RACHIDI, M., LOPES, C., VAYSSETTES, C., SMITH, D. J., RUBIN, E. M. \& DELABAR, J. M. 2007. New cerebellar phenotypes in YAC transgenic mouse in vivo library of human Down syndrome critical region-1. Biochem Biophys Res Commun, 364, 488-94.

RACITI, D., REGGIANI, L., GEFFERS, L., JIANG, Q., BACCHION, F., SUBRIZI, A. E., CLEMENTS, D., TINDAL, C., DAVIDSON, D. R., KAISSLING, B. \& BRÄNDLI, A. W. 2008. Organization of the pronephric kidney revealed by large-scale gene expression mapping. Genome Biol, 9, R84.

RAHMANI, Z., BLOUIN, J. L., CREAU-GOLDBERG, N., WATKINS, P. C., MATTEI, J. F., POISSONNIER, M., PRIEUR, M., CHETTOUH, Z., NICOLE, A. \& AURIAS, A. 1989. Critical role of the D21S55 region on chromosome 21 in the pathogenesis of Down syndrome. Proc Natl Acad Sci U S A, 86, 5958-62.

RAMIREZ-SOLIS, R., LIU, P. \& BRADLEY, A. 1995. Chromosome engineering in mice. Nature, $378,720-4$.

RAVEAU, M., LIGNON, J. M., NALESSO, V., DUCHON, A., GRONER, Y., SHARP, A. J., DEMBELE, D., BRAULT, V. \& HÉRAULT, Y. 2012. The app-runx1 region is critical for birth defects and electrocardiographic dysfunctions observed in a down syndrome mouse model. PLoS Genet, 8, e1002724.

RAVEAU, M., NAKAHARI, T., ASADA, S., ISHIHARA, K., AMANO, K., SHIMOHATA, A., SAGO, H. \& YAMAKAWA, K. 2017. Brain ventriculomegaly in Down syndrome mice is caused by Pcp4 dose-dependent cilia dysfunction. Hum Mol Genet, 26, 923-931.

RAVEAU, M., SHIMOHATA, A., AMANO, K., MIYAMOTO, H. \& YAMAKAWA, K. 2018. DYRK1Ahaploinsufficiency in mice causes autistic-like features and febrile seizures. Neurobiol Dis, 110, 180-191.

REEVES, R. H., IRVING, N. G., MORAN, T. H., WOHN, A., KITT, C., SISODIA, S. S., SCHMIDT, C., BRONSON, R. T. \& DAVISSON, M. T. 1995. A mouse model for Down syndrome exhibits learning and behaviour deficits. Nat Genet, 11, 177-84.

REYNOLDS, L. E., WATSON, A. R., BAKER, M., JONES, T. A., D'AMICO, G., ROBINSON, S. D., JOFFRE, C., GARRIDO-URBANI, S., RODRIGUEZ-MANZANEQUE, J. C., MARTINOECHARRI, E., AURRAND-LIONS, M., SHEER, D., DAGNA-BRICARELLI, F., NIZETIC, D., MCCABE, C. J., TURNELL, A. S., KERMORGANT, S., IMHOF, B. A., ADAMS, R., FISHER, E. M. C., TYBULEWICZ, V. L. J., HART, I. R. \& HODIVALA-DILKE, K. M. 2010. Tumour angiogenesis is reduced in the Tc1 mouse model of Down's syndrome. Nature, 465, 813-817.

RICHARD, F. \& DUTRILLAUX, B. 1998. Origin of human chromosome 21 and its consequences: a 50-million-year-old story. Chromosome Res, 6, 263-8.

RICHTSMEIER, J. T., BAXTER, L. L. \& REEVES, R. H. 2000. Parallels of craniofacial maldevelopment in Down syndrome and Ts65Dn mice. Dev Dyn, 217, 137-45.

RICHTSMEIER, J. T., ZUMWALT, A., CARLSON, E. J., EPSTEIN, C. J. \& REEVES, R. H. 2002. Craniofacial phenotypes in segmentally trisomic mouse models for Down syndrome. Am J Med Genet, 107, 317-24.

ROHAN, R. M., KING, D. \& FRELS, W. I. 1990. Direct sequencing of PCR-amplified junction fragments from tandemly repeated transgenes. Nucleic Acids Res, 18, 6089-95.

ROIZEN, N. J. \& PATTERSON, D. 2003. Down's syndrome. Lancet, 361, 1281-9. 
ROPER, R. J., BAXTER, L. L., SARAN, N. G., KLINEDINST, D. K., BEACHY, P. A. \& REEVES, R. H. 2006. Defective cerebellar response to mitogenic Hedgehog signaling in Down [corrected] syndrome mice. Proc Natl Acad Sci U S A, 103, 1452-6.

ROUBERTOUX, P. L., BICHLER, Z., PINOTEAU, W., JAMON, M., SEREGAZA, Z., SMITH, D. J., RUBIN, E. \& MIGLIORE-SAMOUR, D. 2006. Pre-weaning sensorial and motor development in mice transpolygenic for the critical region of trisomy 21 . Behav Genet, 36, 377-86.

ROWE, J., LAVENDER, A. \& TURK, V. 2006. Cognitive executive function in Down's syndrome. Br J Clin Psychol, 45, 5-17.

RUEDA, N., LLORENS-MARTíN, M., FLÓREZ, J., VALDIZÁN, E., BANERJEE, P., TREJO, J. L. \& MARTÍNEZ-CUÉ, C. 2010. Memantine normalizes several phenotypic features in the Ts65Dn mouse model of Down syndrome. J Alzheimers Dis, 21, 277-90.

RYOO, S. R., CHO, H. J., LEE, H. W., JEONG, H. K., RADNAABAZAR, C., KIM, Y. S., KIM, M. J., SON, M. Y., SEO, H., CHUNG, S. H. \& SONG, W. J. 2008. Dual-specificity tyrosine(Y)phosphorylation regulated kinase $1 \mathrm{~A}$-mediated phosphorylation of amyloid precursor protein: evidence for a functional link between Down syndrome and Alzheimer's disease. J Neurochem, 104, 1333-44.

SAGO, H., CARLSON, E. J., SMITH, D. J., KILBRIDGE, J., RUBIN, E. M., MOBLEY, W. C., EPSTEIN, C. J. \& HUANG, T. T. 1998. Ts1Cje, a partial trisomy 16 mouse model for Down syndrome, exhibits learning and behavioral abnormalities. Proc Natl Acad Sci U S A, 95, 6256-61.

SAGO, H., CARLSON, E. J., SMITH, D. J., RUBIN, E. M., CRNIC, L. S., HUANG, T. T. \& EPSTEIN, C. J. 2000. Genetic dissection of region associated with behavioral abnormalities in mouse models for Down syndrome. Pediatr Res, 48, 606-13.

SALEHI, A., DELCROIX, J. D., BELICHENKO, P. V., ZHAN, K., WU, C., VALLETTA, J. S., TAKIMOTO-KIMURA, R., KLESCHEVNIKOV, A. M., SAMBAMURTI, K., CHUNG, P. P., XIA, W., VILLAR, A., CAMPBELL, W. A., KULNANE, L. S., NIXON, R. A., LAMB, B. T., EPSTEIN, C. J., STOKIN, G. B., GOLDSTEIN, L. S. \& MOBLEY, W. C. 2006. Increased App expression in a mouse model of Down's syndrome disrupts NGF transport and causes cholinergic neuron degeneration. Neuron, 51, 29-42.

SAUNDERS, A., MACOSKO, E. Z., WYSOKER, A., GOLDMAN, M., KRIENEN, F. M., DE RIVERA, H., BIEN, E., BAUM, M., BORTOLIN, L., WANG, S., GOEVA, A., NEMESH, J., KAMITAKI, N., BRUMBAUGH, S., KULP, D. \& MCCARROLL, S. A. 2018. Molecular Diversity and Specializations among the Cells of the Adult Mouse Brain. Cell, 174, 1015-1030.e16.

SCALES, T. M., LIN, S., KRAUS, M., GOOLD, R. G. \& GORDON-WEEKS, P. R. 2009. Nonprimed and DYRK1A-primed GSK3 beta-phosphorylation sites on MAP1B regulate microtubule dynamics in growing axons. J Cell Sci, 122, 2424-35.

SCHMITT, A. D., HU, M., JUNG, I., XU, Z., QIU, Y., TAN, C. L., LI, Y., LIN, S., LIN, Y., BARR, C. L. \& REN, B. 2016. A Compendium of Chromatin Contact Maps Reveals Spatially Active Regions in the Human Genome. Cell Rep, 17, 2042-2059.

SEBRIE, C., CHABERT, C., LEDRU, A., GUEDJ, F., PO, C., SMITH, D. J., RUBIN, E., RIVALS, I., BELOEIL, J. C., GILLET, B. \& DELABAR, J. M. 2008. Increased Dosage of DYRK1A and Brain Volumetric Alterations in a YAC Model of Partial Trisomy 21. Anat Rec (Hoboken), 291, 254-262.

SHINOHARA, T., TOMIZUKA, K., MIYABARA, S., TAKEHARA, S., KAZUKI, Y., INOUE, J., KATOH, M., NAKANE, H., IINO, A., OHGUMA, A., IKEGAMI, S., INOKUCHI, K., ISHIDA, I., REEVES, R. H. \& OSHIMURA, M. 2001. Mice containing a human chromosome 21 
model behavioral impairment and cardiac anomalies of Down's syndrome. Hum Mol Genet, 10, 1163-75.

SHUKKUR, E. A., SHIMOHATA, A., AKAGI, T., YU, W., YAMAGUCHI, M., MURAYAMA, M., CHUI, D., TAKEUCHI, T., AMANO, K., SUBRAMHANYA, K. H., HASHIKAWA, T., SAGO, H., EPSTEIN, C. J., TAKASHIMA, A. \& YAMAKAWA, K. 2006. Mitochondrial dysfunction and tau hyperphosphorylation in Ts1Cje, a mouse model for Down syndrome. Hum Mol Genet, 15, 2752-62.

SIAREY, R. J., STOLL, J., RAPOPORT, S. I. \& GALDZICKI, Z. 1997. Altered long-term potentiation in the young and old Ts65Dn mouse, a model for Down Syndrome. Neuropharmacology, 36, 1549-54.

SIMÓN, A. M., SCHIAPPARELLI, L., SALAZAR-COLOCHO, P., CUADRADO-TEJEDOR, M., ESCRIBANO, L., LÓPEZ DE MATURANA, R., DEL RÍO, J., PÉREZ-MEDIAVILLA, A. \& FRECHILLA, D. 2009. Overexpression of wild-type human APP in mice causes cognitive deficits and pathological features unrelated to Abeta levels. Neurobiol Dis, 33, 36978.

SMIRNOV, A. V., KONTSEVAYA, G. V., FEOFANOVA, N. A., ANISIMOVA, M. V., SEROVA, I. A., GERLINSKAYA, L. A., BATTULIN, N. R., MOSHKIN, M. P. \& SEROV, O. L. 2018. Unexpected phenotypic effects of a transgene integration causing a knockout of the endogenous Contactin-5 gene in mice. Transgenic Res, 27, 1-13.

SMITH, D. J. \& RUBIN, E. M. 1997. Functional screening and complex traits: human 21q22.2 sequences affecting learning in mice. Human Molecular Genetics, 6, 1729-1733.

SMITH, D. J., STEVENS, M. E., CHENG, J. F. \& RUBIN, E. M. 1997. Identification of genes affecting learning and memory in chromosome 21 YAC transgenic mice. Cytogenetics and Cell Genetics, 79, 49-49.

SMITH, D. J., ZHU, Y. W., ZHANG, J. L., CHENG, J. F. \& RUBIN, E. M. 1995. CONSTRUCTION OF A PANEL OF TRANSGENIC MICE CONTAINING A CONTIGUOUS 2-MB SET OF YAC/P1 CLONES FROM HUMAN-CHROMOSOME 21Q22.2. Genomics, 27, 425-434.

SONG, W. J., SONG, E. A., CHOI, S. H., BAIK, H. H., JIN, B. K., KIM, J. H. \& CHUNG, S. H. 2013. Dyrk1A-mediated phosphorylation of RCAN1 promotes the formation of insoluble RCAN1 aggregates. Neurosci Lett, 554, 135-40.

SONG, W. J., SONG, E. A., JUNG, M. S., CHOI, S. H., BAIK, H. H., JIN, B. K., KIM, J. H. \& CHUNG, S. H. 2015. Phosphorylation and inactivation of glycogen synthase kinase $3 \beta$ (GSK3 $\beta$ ) by dual-specificity tyrosine phosphorylation-regulated kinase $1 \mathrm{~A}$ (Dyrk1A). J Biol Chem, 290, 2321-33.

SOPPA, U., SCHUMACHER, J., FLORENCIO ORTIZ, V., PASQUALON, T., TEJEDOR, F. J. \& BECKER, W. 2014. The Down syndrome-related protein kinase DYRK1A phosphorylates p27(Kip1) and Cyclin D1 and induces cell cycle exit and neuronal differentiation. Cell Cycle, 13, 2084-100.

SOUCHET, B., GUEDJ, F., PENKE-VERDIER, Z., DAUBIGNEY, F., DUCHON, A., HERAULT, Y., BIZOT, J. C., JANEL, N., CRÉAU, N., DELATOUR, B. \& DELABAR, J. M. 2015. Pharmacological correction of excitation/inhibition imbalance in Down syndrome mouse models. Front Behav Neurosci, 9, 267.

SOUCHET, B., GUEDJ, F., SAHÚN, I., DUCHON, A., DAUBIGNEY, F., BADEL, A., YANAGAWA, Y., BARALLOBRE, M. J., DIERSSEN, M., YU, E., HERAULT, Y., ARBONES, M., JANEL, N., CRÉAU, N. \& DELABAR, J. M. 2014. Excitation/inhibition balance and learning are modified by Dyrk1a gene dosage. Neurobiol Dis, 69, 65-75. 
STARBUCK, J. M., DUTKA, T., RATLIFF, T. S., REEVES, R. H. \& RICHTSMEIER, J. T. 2014. Overlapping trisomies for human chromosome 21 orthologs produce similar effects on skull and brain morphology of Dp(16)1Yey and Ts65Dn mice. Am J Med Genet $A$, 164A, 1981-90.

STOLL, C., DOTT, B., ALEMBIK, Y. \& ROTH, M. P. 2015. Associated congenital anomalies among cases with Down syndrome. Eur J Med Genet, 58, 674-80.

TASIC, B., MENON, V., NGUYEN, T. N., KIM, T. K., JARSKY, T., YAO, Z., LEVI, B., GRAY, L. T., SORENSEN, S. A., DOLBEARE, T., BERTAGNOLLI, D., GOLDY, J., SHAPOVALOVA, N., PARRY, S., LEE, C., SMITH, K., BERNARD, A., MADISEN, L., SUNKIN, S. M., HAWRYLYCZ, M., KOCH, C. \& ZENG, H. 2016. Adult mouse cortical cell taxonomy revealed by single cell transcriptomics. Nat Neurosci, 19, 335-46.

TEJEDOR, F. J. \& HÄMMERLE, B. 2011. MNB/DYRK1A as a multiple regulator of neuronal development. FEBS J, 278, 223-35.

THOMAZEAU, A., LASSALLE, O., IAFRATI, J., SOUCHET, B., GUEDJ, F., JANEL, N., CHAVIS, P., DELABAR, J. \& MANZONI, O. J. 2014. Prefrontal deficits in a murine model overexpressing the down syndrome candidate gene dyrk1a. J Neurosci, 34, 1138-47.

TOIBER, D., AZKONA, G., BEN-ARI, S., TORÁN, N., SOREQ, H. \& DIERSSEN, M. 2010. Engineering DYRK1A overdosage yields Down syndrome-characteristic cortical splicing aberrations. Neurobiol Dis, 40, 348-59.

TOYODA, A., NOGUCHI, H., TAYLOR, T. D., ITO, T., PLETCHER, M. T., SAKAKI, Y., REEVES, R. H. \& HATTORI, M. 2002. Comparative genomic sequence analysis of the human chromosome 21 Down syndrome critical region. Genome Res, 12, 1323-32.

TROCA-MARÍN, J. A., CASAÑAS, J. J., BENITO, I. \& MONTESINOS, M. L. 2014. The Akt-mTOR pathway in Down's syndrome: the potential use of rapamycin/rapalogs for treating cognitive deficits. CNS Neurol Disord Drug Targets, 13, 34-40.

VALENTI, D., DE BARI, L., DE RASMO, D., SIGNORILE, A., HENRION-CAUDE, A., CONTESTABILE, A. \& VACCA, R. A. 2016. The polyphenols resveratrol and epigallocatechin-3-gallate restore the severe impairment of mitochondria in hippocampal progenitor cells from a Down syndrome mouse model. Biochim Biophys Acta, 1862, 1093-104.

VALENTI, D., MANENTE, G. A., MORO, L., MARRA, E. \& VACCA, R. A. 2011. Deficit of complex I activity in human skin fibroblasts with chromosome 21 trisomy and overproduction of reactive oxygen species by mitochondria: involvement of the cAMP/PKA signalling pathway. Biochem J, 435, 679-88.

VALENTI, D., ROSSI, L., MARZULLI, D., BELLOMO, F., DE RASMO, D., SIGNORILE, A. \& VACCA, R. A. 2017. Inhibition of Drp1-mediated mitochondrial fission improves mitochondrial dynamics and bioenergetics stimulating neurogenesis in hippocampal progenitor cells from a Down syndrome mouse model. Biochim Biophys Acta Mol Basis Dis, 1863, 3117-3127.

VALENTI, D., TULLO, A., CARATOZZOLO, M. F., MERAFINA, R. S., SCARTEZZINI, P., MARRA, E. \& VACCA, R. A. 2010. Impairment of F1F0-ATPase, adenine nucleotide translocator and adenylate kinase causes mitochondrial energy deficit in human skin fibroblasts with chromosome 21 trisomy. Biochem J, 431, 299-310.

VICARI, S., BELLUCCI, S. \& CARLESIMO, G. A. 2000. Implicit and explicit memory: a functional dissociation in persons with Down syndrome. Neuropsychologia, 38, 240-251.

VICARI, S., BELLUCCI, S. \& CARLESIMO, G. A. 2005. Visual and spatial long-term memory: differential pattern of impairments in Williams and Down syndromes. Dev Med Child Neurol, 47, 305-11. 
VILARdelL, M., RASCHE, A., THORMANN, A., MASCHKE-DUTZ, E., PÉREZ-JURAdo, L. A., LEHRACH, H. \& HERWIG, R. 2011. Meta-analysis of heterogeneous Down Syndrome data reveals consistent genome-wide dosage effects related to neurological processes. BMC Genomics, 12, 229.

VINGTDEUX, V., HAMDANE, M., GOMPEL, M., BÉGARD, S., DROBECQ, H., GHESTEM, A., GROSJEAN, M. E., KOSTANJEVECKI, V., GROGNET, P., VANMECHELEN, E., BUÉE, L., DELACOURTE, A. \& SERGEANT, N. 2005. Phosphorylation of amyloid precursor carboxy-terminal fragments enhances their processing by a gamma-secretasedependent mechanism. Neurobiol Dis, 20, 625-37.

VORONOV, S. V., FRERE, S. G., GIOVEDI, S., POLLINA, E. A., BOREL, C., ZHANG, H., SCHMIDT, C., AKESON, E. C., WENK, M. R., CIMASONI, L., ARANCIO, O., DAVISSON, M. T., ANTONARAKIS, S. E., GARDINER, K., DE CAMILLI, P. \& DI PAOLO, G. 2008. Synaptojanin 1-linked phosphoinositide dyshomeostasis and cognitive deficits in mouse models of Down's syndrome. Proc Natl Acad Sci U S A, 105, 9415-20.

WANG, X., ZHAO, Y., ZHANG, X., BADIE, H., ZHOU, Y., MU, Y., LOO, L. S., CAI, L., THOMPSON, R. C., YANG, B., CHEN, Y., JOHNSON, P. F., WU, C., BU, G., MOBLEY, W. C., ZHANG, D., GAGE, F. H., RANSCHT, B., ZHANG, Y. W., LIPTON, S. A., HONG, W. \& XU, H. 2013. LosS of sorting nexin 27 contributes to excitatory synaptic dysfunction by modulating glutamate receptor recycling in Down's syndrome. Nat Med, 19, 473-80.

WANG, X. T., CUI, W. \& PENG, C. 2017. HiTAD: detecting the structural and functional hierarchies of topologically associating domains from chromatin interactions. Nucleic Acids Res, 45, e163.

WATERSTON, R. H., LINDBLAD-TOH, K., BIRNEY, E., ROGERS, J., ABRIL, J. F., AGARWAL, P., AGARWALA, R., AINSCOUGH, R., ALEXANDERSSON, M., AN, P., ANTONARAKIS, S. E., ATTWOOD, J., BAERTSCH, R., BAILEY, J., BARLOW, K., BECK, S., BERRY, E., BIRREN, B., BLOOM, T., BORK, P., BOTCHERBY, M., BRAY, N., BRENT, M. R., BROWN, D. G., BROWN, S. D., BULT, C., BURTON, J., BUTLER, J., CAMPBELL, R. D., CARNINCI, P., CAWLEY, S., CHIAROMONTE, F., CHINWALLA, A. T., CHURCH, D. M., CLAMP, M., CLEE, C., COLLINS, F. S., COOK, L. L., COPLEY, R. R., COULSON, A., COURONNE, O., CUFF, J., CURWEN, V., CUTTS, T., DALY, M., DAVID, R., DAVIES, J., DELEHAUNTY, K. D., DERI, J., DERMITZAKIS, E. T., DEWEY, C., DICKENS, N. J., DIEKHANS, M., DODGE, S., DUBCHAK, I., DUNN, D. M., EDDY, S. R., ELNITSKI, L., EMES, R. D., ESWARA, P., EYRAS, E., FELSENFELD, A., FEWELL, G. A., FLICEK, P., FOLEY, K., FRANKEL, W. N., FULTON, L. A., FULTON, R. S., FUREY, T. S., GAGE, D., GIBBS, R. A., GLUSMAN, G., GNERRE, S., GOLDMAN, N., GOODSTADT, L., GRAFHAM, D., GRAVES, T. A., GREEN, E. D., GREGORY, S., GUIGO, R., GUYER, M., HARDISON, R. C., HAUSSLER, D., HAYASHIZAKI, Y., HILLIER, L. W., HINRICHS, A., HLAVINA, W., HOLZER, T., HSU, F., HUA, A., HUBBARD, T., HUNT, A., JACKSON, I., JAFFE, D. B., JOHNSON, L. S., JONES, M., JONES, T. A., JOY, A., KAMAL, M., KARLSSON, E. K., et al. 2002. Initial sequencing and comparative analysis of the mouse genome. Nature, 420, 520-62.

WATSON-SCALES, S., KALMAR, B., LANA-ELOLA, E., GIBBINS, D., LA RUSSA, F., WISEMAN, F., WILLIAMSON, M., SACCON, R., SLENDER, A., OLERINYOVA, A., MAHMOOD, R., NYE, E., CATER, H., WELLS, S., YU, Y. E., BENNETT, D. L. H., GREENSMITH, L., FISHER, E. M. C. \& TYBULEWICZ, V. L. J. 2018. Analysis of motor dysfunction in Down Syndrome reveals motor neuron degeneration. PLoS Genet, 14, e1007383.

WEGIEL, J., KACZMARSKI, W., BARUA, M., KUCHNA, I., NOWICKI, K., WANG, K. C., YANG, S. M., FRACKOWIAK, J., MAZUR-KOLECKA, B., SILVERMAN, W. P., REISBERG, B., 
MONTEIRO, I., DE LEON, M., WISNIEWSKI, T., DALTON, A., LAI, F., HWANG, Y. W., ADAYEV, T., LIU, F., IQBAL, K., IQBAL, I. G. \& GONG, C. X. 2011. Link between DYRK1A overexpression and several-fold enhancement of neurofibrillary degeneration with 3repeat tau protein in Down syndrome. J Neuropathol Exp Neurol, 70, 36-50.

WISEMAN, F. K., AL-JANABI, T., HARDY, J., KARMILOFF-SMITH, A., NIZETIC, D., TYBULEWICZ, V. L., FISHER, E. M. \& STRYDOM, A. 2015. A genetic cause of Alzheimer disease: mechanistic insights from Down syndrome. Nat Rev Neurosci, 16, 564-74.

WISNIEWSKI, K. E., DALTON, A. J., MCLACHLAN, C., WEN, G. Y. \& WISNIEWSKI, H. M. 1985. Alzheimer's disease in Down's syndrome: clinicopathologic studies. Neurology, 35, 957-61.

WONG, H., LEVENGA, J., CAIN, P., ROTHERMEL, B., KLANN, E. \& HOEFFER, C. 2015. RCAN1 overexpression promotes age-dependent mitochondrial dysregulation related to neurodegeneration in Alzheimer's disease. Acta Neuropathol, 130, 829-43.

WOODS, Y. L., COHEN, P., BECKER, W., JAKES, R., GOEDERT, M., WANG, X. \& PROUD, C. G. 2001. The kinase DYRK phosphorylates protein-synthesis initiation factor elF2Bepsilon at Ser539 and the microtubule-associated protein tau at Thr212: potential role for DYRK as a glycogen synthase kinase 3-priming kinase. Biochem J, 355, 609-15.

XING, L., SALAS, M., ZHANG, H., GITTLER, J., LUDWIG, T., LIN, C. S., MURTY, V. V., SILVERMAN, W., ARANCIO, O. \& TYCKO, B. 2013. Creation and characterization of BAC-transgenic mice with physiological overexpression of epitope-tagged RCAN1 (DSCR1). Mamm Genome, 24, 30-43.

YABUT, O., DOMOGAUER, J. \& D'ARCANGELO, G. 2010. Dyrk1A overexpression inhibits proliferation and induces premature neuronal differentiation of neural progenitor cells. J Neurosci, 30, 4004-14.

YAN, B. W., ZHAO, Y. F., CAO, W. G., LI, N. \& GOU, K. M. 2013. Mechanism of random integration of foreign DNA in transgenic mice. Transgenic Res, 22, 983-92.

YANG, E. J., AHN, Y. S. \& CHUNG, K. C. 2001. Protein kinase Dyrk1 activates cAMP response element-binding protein during neuronal differentiation in hippocampal progenitor cells. J Biol Chem, 276, 39819-24.

YOKOYAMA, S., ITO, Y., UENO-KUDOH, H., SHIMIZU, H., UCHIBE, K., ALBINI, S., MITSUOKA, K., MIYAKI, S., KISO, M., NAGAI, A., HIKATA, T., OSADA, T., FUKUDA, N., YAMASHITA, S., HARADA, D., MEZZANO, V., KASAI, M., PURI, P. L., HAYASHIZAKI, Y., OKADO, H., HASHIMOTO, M. \& ASAHARA, H. 2009. A systems approach reveals that the myogenesis genome network is regulated by the transcriptional repressor RP58. Dev Cell, 17, 836-48.

YU, T., LI, Z., JIA, Z., CLAPCOTE, S., LIU, C., LI, S., ASRAR, S., PAO, A., CHEN, R., FAN, N., CARATTINI-RIVERA, S., BECHARD, A., SPRING, S., HENKELMAN, R., STOICA, G., MATSUI, S., NOWAK, N., RODER, J., CHEN, C., BRADLEY, A. \& YU, Y. 2010a. A mouse model of Down syndrome trisomic for all human chromosome 21 syntenic regions. Hum Mol Genet, 19, 2780-91.

YU, T., LI, Z., JIA, Z., CLAPCOTE, S. J., LIU, C., LI, S., ASRAR, S., PAO, A., CHEN, R., FAN, N., CARATTINI-RIVERA, S., BECHARD, A. R., SPRING, S., HENKELMAN, R. M., STOICA, G., MATSUI, S., NOWAK, N. J., RODER, J. C., CHEN, C., BRADLEY, A. \& YU, Y. E. 2010b. A mouse model of Down syndrome trisomic for all human chromosome 21 syntenic regions. Hum Mol Genet, 19, 2780-91. 
YU, T., LIU, C. H., BELICHENKO, P., CLAPCOTE, S. J., LI, S. M., PAO, A. N., KLESCHEVNIKOV, A., BECHARD, A. R., ASRAR, S., CHEN, R. Q., FAN, N., ZHOU, Z. Y., JIA, Z. P., CHEN, C., RODER, J. C., LIU, B., BALDINI, A., MOBLEY, W. C. \& YU, Y. E. 2010c. Effects of individual segmental trisomies of human chromosome 21 syntenic regions on hippocampal long-term potentiation and cognitive behaviors in mice. Brain Research, 1366, 162-171.

ZHANG, J., BARAN, J., CROS, A., GUBERMAN, J. M., HAIDER, S., HSU, J., LIANG, Y., RIVKIN, E., WANG, J., WHITTY, B., WONG-ERASMUS, M., YAO, L. \& KASPRZYK, A. 2011. International Cancer Genome Consortium Data Portal--a one-stop shop for cancer genomics data. Database (Oxford), 2011, bar026.

ZHANG, L., MENG, K., JIANG, X., LIU, C., PAO, A., BELICHENKO, P. V., KLESCHEVNIKOV, A. M., JOSSELYN, S., LIANG, P., YE, P., MOBLEY, W. C. \& YU, Y. E. 2014. Human chromosome 21 orthologous region on mouse chromosome 17 is a major determinant of Down syndrome-related developmental cognitive deficits. Hum Mol Genet, 23, 578-89.

ZHANG, X., ZHANG, Y., ZHU, X., PURMANN, C., HANEY, M. S., WARD, T., KHECHADURI, A., YAO, J., WEISSMAN, S. M. \& URBAN, A. E. 2018. Local and global chromatin interactions are altered by large genomic deletions associated with human brain development. Nat Commun, 9, 5356.

ZHENG-BRADLEY, X., RUNG, J., PARKINSON, H. \& BRAZMA, A. 2010. Large scale comparison of global gene expression patterns in human and mouse. Genome Biol, 11, R124.

\section{Tables}

\begin{tabular}{|c|c|c|c|c|c|c|c|c|c|c|}
\hline & Human & Gorilla & Chimpanzee & Orangutan & Mouse & Rat & Zebrafish & Drosophila & C.elegans \\
\hline \multirow{2}{*}{\multicolumn{2}{|c|}{$\begin{array}{l}\text { Nb Human Genes Chr21 } \\
\text { Nb genes without } \\
\text { homolog }\end{array}$}} & 815 & & & & & & & & \\
\hline & & & 569 & 554 & 583 & 607 & 602 & 661 & 717 & 732 \\
\hline \multicolumn{2}{|c|}{ Nb homologs found } & & 246 & 261 & 232 & 208 & 213 & 154 & 98 & 83 \\
\hline \multirow{5}{*}{$\begin{array}{c}\mathrm{Nb} \\
\text { homologs } \\
\text { per } \\
\text { biotype } \\
\text { category }\end{array}$} & $\begin{array}{l}\text { Protein } \\
\text { coding }\end{array}$ & 232 & 200 & 207 & 193 & 192 & 193 & 143 & 97 & 83 \\
\hline & sncRNA & 75 & 46 & 54 & 39 & 16 & 20 & 11 & 1 & - \\
\hline & IncRNA & 305 & - & - & - & - & - & - & - & - \\
\hline & Pseudogenes & 188 & - & - & - & - & - & - & - & - \\
\hline & TEC & 15 & - & - & - & - & - & - & - & - \\
\hline \multirow{5}{*}{$\begin{array}{c}\text { Nb genes } \\
\text { without } \\
\text { homolog } \\
\text { per } \\
\text { biotype } \\
\text { category }\end{array}$} & $\begin{array}{l}\text { Protein } \\
\text { coding }\end{array}$ & & 32 & 25 & 39 & 40 & 39 & 89 & 135 & 149 \\
\hline & sncRNA & & 29 & 21 & 36 & 59 & 55 & 64 & 74 & 305 \\
\hline & IncRNA & & 305 & 305 & 305 & 305 & 305 & 305 & 305 & 188 \\
\hline & Pseudogenes & & 188 & 188 & 188 & 188 & 188 & 188 & 188 & 75 \\
\hline & TEC & & 15 & 15 & 15 & 15 & 15 & 15 & 15 & 15 \\
\hline
\end{tabular}

Table 1: Homologs to Hsa21 found in other species. Identifying the different number per biotype category and biotype. The data were denerated querying the ENSEMBL database using biomaRt on the 270219. The used assembly's database versions are GRCh38.p12.v95, GRCm38.p6.v95, Rnor_6.0.v95, BDGP6.v95, Pan_tro 3.0.v95, gorGor4.v95, PPYG2.v95, 
GRCz11.v95, WBcel235.v95. The number of genes per chromosome and per biotype category across species is indicated.

\begin{tabular}{|c|c|c|c|}
\hline Phenotypes & $\begin{array}{l}\text { Nb of } \\
\text { genes }\end{array}$ & $\begin{array}{c}\text { Nb of } \\
\text { Phenotypes }\end{array}$ & List of genes \\
\hline $\begin{array}{l}\text { behaviour/ neurological/ nervous } \\
\text { system }\end{array}$ & 22 & 61 & $\begin{array}{l}\text { App, Atp5o, Bach1, Cbr3, Col18a1, Col6a2, Cstb, Dnajc28, } \\
\text { Dop1b, Mx2, Pknox1, Synj1, Tiam1, Tmem50b,Trappc10, Kcne2 } \\
\text { Hunk, Mx2, Rcan1 }\end{array}$ \\
\hline Pre-natal or early mortality & 16 & 46 & $\begin{array}{l}\text { Agpat3, Aire, App, Atp5o, Bach1, Erg, Gabpa, Gart, Hlcs, Lss, } \\
\text { Morc3, Pdxk, Pfkl, Psmg1, Synj1, Wrb }\end{array}$ \\
\hline homeostasis/metabolism & 19 & 49 & $\begin{array}{l}\text { 4932438H23Rik, Agpat3, App, Bach1, Col18a1, Dnajc28, } \\
\text { Dop1b, Fam207a, Hsf2bp, Il1Orb, Kcne2, Lrrc3, Pknox1, S100b, } \\
\text { Setd4, Spatc1l, Tff1, Hsf2bp, Slc37a1 }\end{array}$ \\
\hline growth/ size/ body region & 13 & 35 & $\begin{array}{l}\text { Chodl, Gart, Hsf2bp, Kcne2, Mx1, Ripk4, Sik1, Tff1, Tmprss15, } \\
\text { Trappc10, Gabpa, Erg, Wrb }\end{array}$ \\
\hline hematopoietic system & 9 & 23 & $\begin{array}{l}\text { Hsf2bp, Kcne2, Pknox1, Rbm11, Ripply3, S100b, Synj1, Tff1, } \\
\text { Trappc10 }\end{array}$ \\
\hline immune system & 8 & 19 & $\begin{array}{l}\text { 1810043G02Rik, Brwd1, Ifnar1, Lrrc3, Lss, Pknox1, Synj1, } \\
\text { Tmprss15, Hsf2bp }\end{array}$ \\
\hline skeleton & 8 & 15 & Cbr3, Chodl, Dop1b, Sik1, Trappc10, Cstb, Setd4, Trappc10 \\
\hline vision/ eye & 6 & 15 & Aire, Col18a1, Gabpa, Lss, Synj1, Ubash3a \\
\hline cardiovascular system & 5 & 9 & Hunk, Sik1, Slc37a1, Col18a1, Lss \\
\hline adipose tissue & 3 & 5 & Rcan1, Sik1,Trappc10 \\
\hline integument & 2 & 3 & Brwd1, Dop1b \\
\hline reproductive system & 3 & 4 & Brwd1, Dnmt3l, Hsf2bp \\
\hline craniofacial & 1 & 1 & Gabpa \\
\hline Hearing system & 1 & 1 & Gabpa \\
\hline
\end{tabular}

Table 2. Hsa21 homologs with known phenotypes in the mouse.

\section{Figure legends}

Figure 1. Comparison of the conserved Hsa21 homologous genes in different species. The respective organisation is preserved, and the localisation of protein-coding genes is indicated in blue square, pseudogenes in green, long non-coding genes in purple, short non-coding in red and genes to be experimentally conserved in orange. Landmarks for LIPI, ZBTB21UMODL1, RPRIB-PDXK and PRMT2 are shown respectively in red, black, grey and black.

Figure 2. Human chromosome 21 syntenic regions in relative closer evolutionary species. The Hsa21 first and last genomic elements are found at 5.011 and $46.69 \mathrm{MBs}$ (in blue). The syntenic regions containing orthologs with a one to one orthology relationship between the human gene and the animal species were used to build this representation. The orthologs genes in the chromosomes of 5 mammals are coloured differently depending on the chromosome they are found (yellow, dark blue, green and red) in the other species. Between brackets the length in MBs of the syntenic region conserved block relative to both the conserved human region length in blue and the length of the syntenic region in the animal species in black.

Figure 3. The DYRK1A region is highly conserved in term of organisation and proteinencoded sequence. A) Evolution tree of the chromosome 21 genes surrounding DYRK1A (arrow). The gene tree was build using Genomicus v95.01 Phyloview and is centred around 
DYRK1A. Every row represents a species and every gene is depicted in a specific colour. The homologs genes appear in the same colour on each species. Shaded genes correspond to genes that are not orthologous to any genes from human. B) Functional and sequence similarity wise DYRKlA gene tree taken from phylomeDB.

Figure 4. TADs located in human chromosome 21 syntenic landscape in the mouse genome. Figures modified from the Yue lab Hi-C browser. http://promoter.bx.psu.edu/hi-c/). Genes in blue are on the reverse strand instead in black are on the forward strand. TADs are represented by the cream/grey bar. The human data displayed corresponds to the cortex Hi$\mathrm{C}$ map from the assembly version $\mathrm{Hg} 19$ with a resolution of $40 \mathrm{Kbs}$ (Schmitt et al., 2016). The Mouse data, displayed corresponds to the neuronal cortex $\mathrm{Hi}-\mathrm{C}$ map with a resolution of 25 Kbs from the assembly version mm10 (Bonev et al., 2017). A) TADs landscape in the Hsa21 syntenic mouse chr16. B) TADs landscape in the Hsa21 syntenic mouse chr17 and chr10.

Figure 5: Models for DS in mouse and rat. Updated from (Herault et al., 2017). The Hsa21 sequence is shown in blue with the corresponding rat (up) and mouse (down) homologous region respectively in Rno11 and 20, or Mmu16, 17 and 10. The relative position of the model is given with the official name and the size of the recombined interval. 